Lucas, L., Fuller, D.Q. Against the Grain: Long-Term Patterns in Agricultural Production in Prehistoric Cyprus. J World Prehist (2020). https://doi.org/10.1007/s10963-020-09140-6

\title{
Against the Grain: Long-Term Patterns in Agricultural Production in Prehistoric Cyprus
}

\section{Leilani Lucas ${ }^{1}$ and Dorian Q. Fuller ${ }^{2,3}$}

${ }^{1}$ College of Southern Nevada, 3200 East Cheyenne Ave S-121, North Las Vegas, NV 89030

${ }^{2}$ University College London, 31-34 Gordon Square, Institute of Archaeology, London, WC1H OPY

${ }^{3}$ School of Archaeology and Museology, Northwest University, Xi'an 710069, Shaanxi, China

Corresponding author email: leilani.lucas@csn.edu

Corresponding author phone number: (702) 6512648

ORCID ID: Leilani Lucas 0000-0002-2917-9863

ORCID ID: Dorian Fuller 0000-0002-4859-080X

\section{Abstract}

Our understanding of the timing and dynamics of the spread of human populations to the island of Cyprus has changed significantly in the last few decades. Ongoing research on a few sites has provided more detail not only on when the initial explorers and farming populations arrived, but also on how the unique culture of prehistoric Cyprus developed. This research explores patterns in the archaeobotanical and zooarchaeological data from prehistoric Cyprus dated from the Neolithic to the Late Bronze Age (c. 8800 to 1300 BC). The data provide insight into a protracted and non-linear transition to an agriculturally- 
focused subsistence strategy on the island, the timing of which demonstrates a deviation from the mainland trajectory. The unique transition includes a prolonged period of intermediate or mixed-subsistence, which involved both a pulling back from cereal agriculture and secondary animal products and a later move, during the Bronze Age, towards perennial land use for crops that could be commodities. The results presented here suggest that, rather than any passive, demographically-driven shift to cereal agriculture, emerging social complexity and active management played key roles.

\section{Keywords}

Archaeobotany $\cdot$ Zooarchaeology $\cdot$ Islands $\cdot$ Early Farming $\cdot$ Mediterranean

\section{Introduction}

Islands provide an alternative perspective on processes of evolution and culture change. In evolutionary biology, one often encounters island processes, for instance the evolution of dwarfism in many larger mammals that find their way to islands (Simmons 1999; Lomolino 2005), or the adaptive radiation of introduced taxa that move into numerous ecological niches, demonstrated by Darwin's finches of the Galapagos (Grant 1981; Losos and Ricklefs 2009). It is not that islands undergo different processes from mainland continents, but rather that island conditions magnify processes of evolution, making them more obvious or perhaps faster. This is in part explicable by the observations of island biogeography that biodiversity is inversely correlated with island size, and smaller land masses or island habitats can support fewer species (MacArthur and Wilson 1967), making species that undergo change appear more obvious. We have previously explored evidence that aspects of domesticated-cereal morphology evolved more rapidly on the island of Cyprus (in particular the increase in grain size among einkorn wheats occurred about twice as fast as on the Near Eastern mainland: Lucas et al. 2012); a similar precociousness is evident in barley grain size. In archaeology there is also literature on 
the distinctiveness of island processes. Some debate surrounds the causes of cultural differences, which have been attributed either to the 'founder effect', with loss of cultural attributes resulting from a bottleneck effect, or to human agency in the context of insularity (see Broodbank 2000). Broodbank (2000, p.19) highlights the role human agency plays in how closed or open cultures are to the influences of the 'outside' world. He states that this can be negotiated and renegotiated depending on unique circumstances, until a point when human choice gives way to influences from beyond, facilitated, for example, by advances in seafaring technologies, as is the case for Cyprus beginning in the second millennium BC. However, before we can discuss the dynamics of cultural, and, more specifically, subsistence change in prehistoric Cyprus we must understand the environment in which these changes unfolded.

\section{Cyprus: The Study Area}

The eastern Mediterranean island of Cyprus was occupied relatively late in human history, with the first humans reaching the island by boat or raft only in the late Epipaleolithic. This is somewhat surprising, as Cyprus is only about $105 \mathrm{~km}$ west of Syria and $65 \mathrm{~km}$ south of Turkey, and on a clear day the island's northern mountains are visible from Turkey. Seafaring technologies and maritime explorations in other regions including Southeast Asia have a much longer history (Vigne et al. 2014; see O'Connell et al. 2010). As an oceanic island, Cyprus was never connected to the surrounding continents and therefore lacks a land-bridge (Held 1989). In the absence of data specifically from Cyprus on both sea level change and tectonic movements during the transition to the Holocene, Vigne and colleagues (2014) summarize evidence from around the Mediterranean basin (see Lambeck and Purcell 2005) and discuss the likely scenario for the earliest maritime voyages to the island. They raise the possibility of a two-step process with a steppingstone islet that might have existed prior to the beginning of the Holocene, but argue that the timing of human occupation likely involved a single step of at least $40 \mathrm{~km}$ by boat or raft. Although Cyprus is surrounded by deep basins (1000-3000 m), with three undersea ridges, only one of the ridges, Misis-Kyrenia, could have emerged as a result of sea level change and tectonic activity in prehistory. The Misis-Kyrenia ridge arises to the west in 
the form of the Kyrenia chain and to the northeast at the Misis mountains, with the highest points in two sea mounts rising above $200 \mathrm{~m}$ below modern-day sea level (bsl), the easternmost mount at $-69 \mathrm{~m}$ bsl (see discussion in Vigne et al. 2014, p.159). Research by Lambeck and Purcell (2005), suggests that sea level may have been lower 12,000 years ago, possibly 40-65 $\mathrm{m}$ lower, and that the mount that culminates at $-69 \mathrm{~m}$ bsl could have emerged at that time; however, the data suggests it would have been quickly submerged thereafter, making a stepping stone islet possible only until the Late PPNA (Vigne et al. 2014). These maritime journeys would have been helped by the winds; however, estimating the exact directions and routes is difficult due to changes in climate and coastal topography (Vigne et al. 2014). The island's paleogeography and position in the eastern Mediterranean help to explain not only the island's late human occupation but its limited range of mammalian fauna prior to human-induced species translocation. A number of sites including Akrotiri-Aetokremnos have contributed to our understanding of this fauna, which, in addition to pygmy hippopotamus (Phanourios minutus) and pygmy elephant (Elephas cypriotes), both species small due to insular dwarfism (Simmons 1999; Horwitz et al. 2004; Vigne 2011), comprises Genetta plesictoides (genet) and Mus cypriacus (Cypriot mouse) (Simmons 1999; see also discussion in Vigne et al. 2014). Although the mammalian fauna lacks diversity, the flora does not, and the earliest humans on the island would, without a doubt, have realized the variety of wild edible plant resources.

Topographically, Cyprus is separated into four regions: 1) the coastal belt; 2) the Kyrenia or northern range; 3) the Troödos or southern range; and 4) the interior lowland Mesaoria or central plain (Zohary 1973; Meikle 1977). The coastal belt is low-lying with mostly rocky shores with some sandy bays and salt-flats (Meikle 1977), and consists of fertile land, both tilled and uncultivated. It can be divided into a number of sub-regions including the Larnaca region (upland and lowland areas); the Polis lowlands; the Ktima lowlands; the Limassol lowlands; and the chalk plateaus of the south (Paphos, Limassol, and Lefkara plateaus). The upland areas of these sub-regions include portions of the lower Troödos massif and the pillow-lava hills, while the lowland regions consist of raised beaches, sand dune formations, gorges, and numerous river terraces (Christodoulou 1959). The 
northern or Kyrenia range runs C. $80 \mathrm{~km}$ parallel to the northern coast and comprises an alpine mountain range (Meikle 1977; Christodoulou 1959). Second to the Kyrenia range, the Troödos mountain range, mostly at an elevation above $1200 \mathrm{~m}$, is the most defining geological feature of the island, and is part of an old mountain system that is in alignment with the African Rift Valley system (Christodoulou 1959; Meikle 1977). The highest elevation (Mt. Olympus, $1950 \mathrm{~m}$ ) comprises igneous rock of dolomite (i.e. igneous dolerites and gabbros), which is surrounded by pillow lavas in the lower elevations surrounding the massif, but clusters primarily in the northeast region and in small outcrops around the island (Christodoulou 1959; Constantinou 1982). These are the locations of two important resources exploited in Cypriot prehistory, namely copper and picrolite (Peltenburg 1982; Steel 2004). In between the Kyrenia and Troödos mountain ranges are the mostly treeless yet fertile central lowlands. The plain runs about $90 \mathrm{~km}$ west to east and is $56 \mathrm{~km}$ wide in the east and $29 \mathrm{~km}$ in the west, with two-thirds of the region lying east of the Troödos mountain recession; it is traversed by seasonally available rivers (Christodoulou 1959; Meikle 1977).

With an arid Mediterranean climate, Cyprus has short, cool, and wet winters and long, dry and hot summers. Regional variation is evident in both temperature and annual rainfall, with differences based primarily on elevation, topography, and season. The annual rainfall ranges from $250 \mathrm{~mm}$ to $1270 \mathrm{~mm}$ per year, with the majority occurring at higher elevations and between October and March (Christodoulou 1959; Meikle 1977). The highest slopes of Mt. Olympus receive, on average, about $1000 \mathrm{~mm}$ of rainfall per year, with the western Mesaoria receiving less than $250 \mathrm{~mm}$ per year (Michaelides et al. 2009). As is characteristic of the region, there are variations in rainfall from year to year and periods of drought are not uncommon (Meikle 1977). The regional rainfall distribution and recurrent droughts have directly impacted current and prehistoric land-use patterns and the stability of the island's agricultural economy. Possible recurrent drought increases the risk of crop failure and limits the availability of fresh water from springs and wells (Christodoulou 1959). Although political circumstances - as well as survey and excavation biases - favour archaeological research in the south and southwest of the island, occupations in earlier phases are located near to streams fed from the major river 
drainages; a shift in site locations - with less access to river drainages and less fertile agricultural land - begins in the Bronze Age, when cattle are re-introduced to the island and plough (ard) technology begins.

The island's vegetation is characterized by eight phytogeographic zones, covered by a range of vegetation groups including: pine forests (i.e. Pinus brutia and Pinus nigra); garigue (or the denser maquis); rocky areas; coastal areas; wetlands; and arable land (Meikle 1977; Tsinides 1998). The island's modern vegetation can be classified phytogeographically as classic Mediterranean with five classes: 1) the Quercetalia calliprini (i.e. Quercetalia and Sarcopoterietalia); 2) the Quercetea cerris orientalia; 3) Cedretea; 4) the central plain; and 5) the narrow alpine zone of the Troödos mountains (Zohary 1973). However, the Quercetalia calliprini and central plain are the only two that provide evidence of human occupation in prehistory, the former extending from sea level to about 1200 m elevation and comprising maquis, batha, and garigue plant communities. There are also aquatic plant communities near rivers and streams where sites were likely to be in prehistory. These are common around the island's coast and include aquatic species of the Phragmitetea and Potamotea classes, which are dominated by Phragmites and sedges (Cyperaceae) including Phragmites australis, Cyperus spp., Eleocharis palustris, and Carex spp. (Meikle 1977; Zohary 1973; see Lucas 2012 for full discussion). Thus, in addition to the edible sedges, the early Cypriots would have had a variety of wild resources available to them, including oak-type maquis vegetation with Olea europaea (olive), Arbutus andrachne (Greek strawberry tree), Pistacia terebinthus (terebinth), and Quercus coccifer (kermes oak) (Meikle 1977; Zohary 1973).

\section{Summary of Human Occupation in Cyprus}

The origin of humans in Cyprus is a complex story of demic diffusion, with evidence of multiple episodes of human activity, along with plant and animal translocations to the island by humans originating from the mainland Levant (Colledge and Conolly 2007; Horwitz et al. 2004; Vigne et al. 2009, 2011). It began with an exploratory phase during the Epipaleolithic (Akrotiri Phase), which may have helped drive to extinction the endemic 
Cypriot pygmy hippopotamus (Simmons 2004). The Pre-Pottery Neolithic (hereafter PPN, with suffixes and prefixes) saw further changes: hunter-cultivators with different varieties of plants and animals in the Cypro-PPNA, a migration of farming populations with more plants and animals in the Cypro-Early PPNB, and additional population movements in later cultural phases (Guiliane and Briois 2001; Peltenburg et al. 2000; Willcox 2003a; Vigne et al. 2011, 2012; Ammerman et al. 2008; McCartney et al. 2007, 2017; Simmons 2004). While the mainland was transitioning from hunting and gathering towards smallscale intensive agro-pastoralism during the PPN (see Bogaard 2004; Fuller, Willcox and Allaby 2011; Bogaard et al. 2014), the island continued to hunt and manage populations of introduced fallow deer (Dama mesopotamica), supplemented by introduced sheep, goat, and, in very low numbers and at very few sites, cattle (Simmons 1999; Croft 1991). With evidence of fallow deer constituting over $70 \%$ of the Cypriot faunal assemblage in many of the Pottery Neolithic and Early Chalcolithic assemblages (Wasse 2007), it has been suggested that shortly after the Near Eastern agricultural package arrived during the Cypro-PPNB the island experienced a form of agricultural de-intensification (Clark et al. 2007). Wasse (2007) suggests that the evolutionary pressures, including increasing populations, that drove agricultural progression on the mainland were absent in Cyprus and as a result, de-intensification occurred. Further, it has been suggested that this subsistence strategy followed a similar pattern of reliance on wild plant food resources (Croft 1991; Button 2010, Murray 1998; Wasse 2007); in other words, hunting of managed populations of deer and gathering of wild food resources went hand in hand. For the first time, evidence from both the archaeobotanical and zooarchaeological records is explored quantitatively to address this previously presumed relationship and the concept of agricultural de-intensification (sites illustrated in Fig. 1).

Moreover, the data from sites dated to the Early Cypro-PPNB through the Cypriot Late Bronze Age (hereafter Cypro-LBA) are compared to allow a better understanding of the relationship between agro-pastoralism, hunting and gathering, and the development of agriculture on the island. This discussion draws attention to the scale of agriculture along the evolutionary continuum of people-plant and people-animal interaction (after Harris 1989; Harris and Fuller 2014), with a recognition of different stages evident in the 
archaeological record, including stages that do not fit the binary hunter-gatherer/farmer classification. We explore the data and highlight a correlation between the scheduling of cereal-based agriculture and the seasonality of deer hunting, which offers insight into the unique trajectory leading up to the Cypriot Bronze Age economy. However, first the terms that will guide the discussion of agricultural developments, must be outlined, defined, and summarized.

\section{Some Definitions}

Definitions of the key terms used in this paper follow established, but not universal, usage and differentiate cultivation, agriculture, and domestication (Harris 1996; Harris and Fuller 2014; Fuller 2007; Price and Bar-Yosef 2011; Zeder 2006). Hunting and gathering involves the exploitation of wild plants and wild animals in their natural habitats, and any modifications to either entail a low investment of labour. Cultivation requires a greater investment of labour and represents a form of human behaviour that is the deliberate manipulation of plant lifecycles. The cultivation of wild plants involves sowing, harvesting and re-planting in tilled soil, and has been identified archaeobotanically by the presence of arable weeds together with morphologically wild cereals, that is, pre-domestication cultivation (Colledge 1998, 2002; Hillman et al. 2001; White and Makarewicz 2011; Willcox 2012). Domestication, on the other hand, involves the genetic changes that altered the adaptations of the plants, with the domesticated plants or animals genetically and morphologically different from their wild progenitor species. These changes are the result of human intervention, whether conscious or unconscious; specifically, due to cultivation practices (for plants) and herding and management strategies (for animals). In other words, the primary difference between cultivation and domestication is that cultivation and animal management practices are things that people do (e.g. tilling, sowing and harvesting), while domestication is a genetic and, often, phenotypically visible property of the plant or animal that increases its adaptation to cultivation and management practices (Fuller 2007; Larson and Fuller 2014; Larson et al. 2014). Nonmorphological changes have also been used to infer domestication status for both plants and animals. These include age profiles, milking, bone pathologies for animals, and 
evidence for the spread of species beyond their natural wild distributions (Meadow 1989; Zeder 2006; Price and Bar-Yosef 2011), although these are not necessarily manifestations of domestication in the strict sense but are used here as possible indicators of management before domestication. Whereas cultivation involves human action and domestication involves genetic change, agriculture is a matter of socioeconomic commitment to the changed and reproductively dependent species. Moreover, we view agriculture as a matter of scale that involves an increase in investment, land-use in which domesticates dominate human consumption, and agricultural economies reserved for those systems that are committed to domesticates (see Harris 2012; Harris and Fuller 2014). In some regions, such as the Near East, this commitment involves a culturally integrated agroecosystem of small-scale intensive garden cultivation and intensive livestock herding, with reciprocal benefits for livestock and crops, that is, the animals provide manure for soil fertilization and help with tillage and the crop by-products are used as fodder (Bogaard 2005).

It is in distinction to culturally integrated agricultural systems that Smith (2001) defines 'low-level food production', in which a majority of calories come from wild rather than cultivated sources (which supply 30-50\%); however, accurate reconstructions of past contributions to overall diet are hard to determine (Miller 2011) without regionally specific ethnographic research (Hadjikoumis 2018). Also, what constitutes deliberately collected wild food resources is difficult to establish (for discussion see Wallace 2019). We have argued elsewhere (Fuller et al. 2018) that the continuum of human plant-management follows patterns of increasing percentages of non-shattering rachises and cereal grain size increase, the two primary indicators for the domestication syndrome visible in the archaeological record, alongside increasing percentages of cultivated products. These elements came together in the Near East in what we argue are agricultural economies in the Middle PPNB as the domestication syndrome in cereals neared fixation, followed in the Late PPNB by a decline in the archaeobotanical record of percentages of wild food taxa, which became scarce by the later Neolithic as diversity in crop packages was also reduced (Fuller et al. 2018). Separate from Smith's 'low-level food production', and continuing with Harris's (2012) recognition of intermediate economies that fall between 
foraging-focused subsistence and later agricultural reliance, we have defined three stages evident in the archaeobotanical record that show a gradual and increasing trend along a continuum that corresponds broadly with cultural chronology and archaeological phasing. The three stages that bring multiple lines and trajectories together are: incipient pre-domestication cultivation (IPDC) (less than $\sim 20 \%$ non-shattering rachises); entrenched pre-domestication cultivation (EPDC) (20-80\% non-shattering rachises, 10$30 \%$ increase in average seed size, $20-80 \%$ of cereals in an assemblage); and domesticated cultivation (DC) (>80\% non-shattering rachises, $>20 \%$ increase in average crop seed size, and $>80 \%$ cereals). We therefore define the assemblages with at least $80 \%$ crop remains as agricultural; assemblages with less than $20 \%$ as foraging-dominant; and those with $20-80 \%$ as intermediate or mixed-subsistence (see Fuller at al 2018). We argue that assemblages that can be considered truly agricultural ( $>80 \%$ of crop remains) become frequent in the Levant only after $7000 \mathrm{BC}$, with wild food reduction in the Late PPN and Pottery Neolithic. Relevant to the current discussion, and highlighted by Fuller and colleagues (2018), are the percentages of cereal crops in a select number of Cypriot sites included in the analysis for sites dated to before $5000 \mathrm{BC}$; in contrast to the mainland, these never reach above $80 \%$. Thus it appears the early Cypriot assemblages lack evidence for agriculturally-reliant economies. This research aims to expand on the number of sites included in the analysis and explore possible reasons for the pattern previously highlighted. Although Wallace and colleagues (2019) take a different methodological approach with evidence from sites dated from 12,000 to 5000 cal. BC, they also argue against the reduction of wild resources during the early Neolithic and for a persistence in what they term 'opportunistic foraging' throughout the PPN.

Shifting the discussion from scale to mode of agriculture, there are differences in agricultural systems that can be discussed in terms of intensive and extensive methods; the former refers to agricultural systems that involve high inputs of labour per unit area, resulting in high area yields, and the latter to systems that involve smaller inputs of labour per unit of land exploited, resulting in smaller area yields (Morrison 1994; Bogaard 2004). In extensive systems, to produce more one must expand cultivation over more land. Both intensification - that is, becoming more intensive - and expansion can produce more and 
create some level of surplus, whether small-scale or large-scale. Processes that might lead to increase in either direction include population increase, land limitations, social demands for more surplus (e.g. for trade), or a combination of these factors (Morrison 1994). However, contrary to widely noted expectations that intensification will accompany population increases and early urbanization (e.g. Trigger 2003, p. 284), Bogaard (2004) argues that the lower population densities of the earlier Neolithic make more intensive, small-scale systems possible (also Bogaard et al. 2013). In contrast, as site size and population densities increase, the amount of intensively cultivated land goes down while the total extent of more extensively cultivated land goes up (Bogaard et al. 2016; Styring et al. 2017). Ethnographic observations in the Mediterranean support this, as intensive systems, requiring manure supply and increased efforts, are only really feasible when fields are a short distance away from households and therefore when communities are relatively small (Halstead 2014). The development of animal traction also facilitated extensification, as larger areas could be tilled with similar amounts of human labour, but without providing more output per unit of land (Wilkinson and Stevens 2008; Halstead 2014).

Models for early Near Eastern agricultural practices have been proposed previously, and include a transition from an intensive mixed-farming system of autumn-sown crops on fixed plots with high inputs of labour through tillage, weeding and manuring (intensification), to floodwater farming and then later to plough-based agriculture with greater woodland clearance (extensification) and large-scale irrigation systems (also extensification) (Bogaard 2004, 2005; Halstead 1987; Sherratt 1980). The agricultural practices for early Cyprus have been described similarly as involving an intensive mixedfarming regime transported from the mainland Levant, with evidence on the island by the end of the ninth millennium BC (Bogaard 2004; Peltenburg et al. 2001). The Cypro-PPNB evidence is suggestive of an integration of small-scale intensive garden cultivation and intensive livestock herding (see Bogaard 2005; Peltenburg 2001). The existence of similarities between the early cultivation practices of the mainland Levant and Cyprus is unsurprising, considering that the agricultural package moved with people to the island. It is only after initial colonization that we begin to see the significance of the 'founder 
effect' discussed above. With regards to crop-based agriculture, there is little evidence for de-intensification, as defined here, of cereal and pulse agriculture during the Ceramic Neolithic and Chalcolithic (Lucas 2014). Quite the opposite: there is evidence for agricultural intensification, which provides support for agricultural practices of lower populations, including diversification of crops (see Lucas 2014). The earliest evidence for extensification comes from the Middle to Late Chalcolithic, with an increase in the number of arable weed taxa in assemblages dated to these periods (Peltenburg 1998; see also Lucas 2014), and later from the Early Bronze Age, with the reintroduction of cattle to the island. The introduction of the cattle-drawn ard in the Early Bronze Age is suggestive of expansion of agricultural fields into new areas with less rainfall and poorer soils (i.e. the central plain), but in closer proximity to the island's copper resources (see Murray 1998; Frankel and Webb 2006; Peltenburg et al. 2003; see also Lucas 2014). This tillage technology corresponds with presumed, albeit limited and dispersed (see Kling and Fall 2010), island-wide population increase and a shift from small-scale intensive to largescale extensive cultivation systems, expanding to more marginal soils, beginning in the Late Chalcolithic (Lucas 2014). Although the aim of this paper is to address the scale of agricultural commitment rather than modes of agricultural systems, as defined above, it is important to summarize previous discussions on local agricultural developments on the island, including the terminology used by different researchers to support their arguments. Thus, what Wasse (2007) refers to as de-intensification likely refers to a reduction in scale or reliance on agriculture, and an increase in hunting, as opposed to a pulling back from 'intensive' agricultural practices, that is, systems that involve high inputs of labour through tillage, weeding and manuring (intensification sensu stricto) and often on a smaller scale.

\section{Prehistoric Cypriot Cultural Complexes}

The research presented here covers the cultural complexes of the Cypriot PPN (c. 88005200 cal. BC); Pottery Neolithic (c. 4700-3900 cal. BC); Chalcolithic (c. 3900-2500 cal. BC); Early and Middle Bronze Ages (c. 2500-1700 cal. BC); and Late Bronze Age (c. 1700-1300 cal. BC) (see Lucas 2014). As stated previously, the story of a human presence on Cyprus begins during the mainland Levantine Natufian, when numerous 
groups of hunter-gatherers visited the island, bringing with them populations of wild boar (Simmons 2004; see also Ammerman et al. 2008). Following Broodbank's (2000) discussion of island archaeology, the extent of contact between Cyprus and the mainland from this time can be described in terms of a sliding scale, from complete independence to complete integration with the mainland network. And as he states (2000, p. 10) 'movement along this scale need not be smooth or gradual, and there is nothing to prevent an island from remaining in the same place on the scale for a long time, and subsequently moving rapidly in either direction'. This could not be more fitting in a description of Cyprus during the Neolithic, Chalcolithic and Bronze Ages. Also, it is imperative to acknowledge the ability to slide along this scale is only possible if insularity is perceived as a negotiable attribute where human agency plays a key role (Broodbank 2000).

The mainland Levantine PPNA sees the beginnings of village life, with circular mud-brick pit-house architecture, hunting of large game (i.e. gazelle, fox, fallow deer, wild boar, and wild cattle), and the earliest evidence for the cultivation of cereals and pulses (Colledge 1998; Hillman and Davis 1990; Bar-Yosef 2001, 2011;Rollefson 2003). It is during this time that populations from the mainland begin to settle in Cyprus (Manning et al. 2010; McCartney 2005; McCartney et al. 2007; Vigne et al. 2012). It is not surprising that the evidence from Cypro-PPNA sites shows strong parallels with the mainland Levant in material culture, architecture (circular) and subsistence (cultivation of wild cereals), including the presence of wild boar, cats, dogs and commensals (Manning et al. 2010; Vigne, Carrere et al. 2011; Vigne, Briois et al. 2012; Vigne, Briois et al. 2017). It could be said that the Cypro-PPNA is towards the far end of the integration scale. It is during the subsequent cultural phase that deviations from the parent populations are evident and the scale begins to tip.

During the mainland PPNB we see multiple changes in architecture (from circular to rectilinear), burial practices, expanding trade networks, population increase and expansion. It is at this time that mainland farming populations colonized the island, bringing with them a suite of domesticated plants and animals (Peltenburg, Colledge et al. 2000; Peltenburg, Bolger et al. 2003), some of which were still undergoing evolution 
of the domestication syndrome in their regions of origin (Fuller, Denham et al.2014; Arranz-Otegui et al. 2016; Fuller, Lucas et al. 2018). The Cypro-Middle PPNB culture parallels the mainland in many respects but begins to diverge from the mainland trajectory beginning in the Cypro-Late PPNB, when it has been suggested that contact with the mainland decreases (Peltenburg 2004). Evidence for decreasing contact comes from differences in the continuation of circular domestic architecture on the island and differences in evolving chipped-stone technologies (Peltenburg, Colledge et al. 2001; Peltenburg, Bolger et al. 2003). The Cypro-PPNB is followed by the Khirokitian culture, which can be described as the pinnacle of the unique Cypriot Neolithic cultural complex, including delayed developments in pottery production, architecture, and social complexity. It is at this point that Cyprus is said to display independence and deviate fully from the mainland culture, not to return to the mainland trajectory until it is integrated into the Bronze Age Mediterranean interaction sphere (see Wasse 2007; McCartney and Gratuze 2003; Peltenburg et al. 1985; Steel 2004).

The Pottery Neolithic, corresponding to the mainland Levantine Chalcolithic, follows a gap in archaeological evidence from about 5300 to $4750 \mathrm{cal}$. BC and spans the period c. 4750 to 3900 cal. BC (Clarke et al. 2007). Although archaeological evidence is more limited than for the preceding periods, chipped stone and ground stone assemblages across the island demonstrate continuity and show similarities with the mainland in material culture (Clarke et al. 2007). This hiatus has been used to support the idea of agricultural deintensification discussed above (see Wasse 2007). The Chalcolithic of Cyprus is contemporary with the Late Chalcolithic and Early Bronze Age of Anatolia, the Levant and Mesopotamia, and it is at this time that the emerging Bronze Age states begin to shape the future of Cypriot culture; Cyprus begins the losing battle of cultural choice and human agency, and with external forces contributing to population growth and demands for Cypriot copper resources, social changes become inevitable. Some of the changes include innovations in art (e.g. symbolic representations), craft production, copper metallurgy and the first signs of social inequality and intensification of ritual (Peltenburg 2010). Throughout the Cypriot Chalcolithic there is evidence for increasing contact with the surrounding regions, in particular, Anatolia (Peltenburg 1998). The level of contact 
increases over the Chalcolithic and debate continues as to whether the changes evident in the Philia and Early Bronze Age are a result of increasing external contact or a possible migration of Anatolian populations beginning in the Late Chalcolithic (Knapp 1993; Manning 1993; Frankel and Webb 1996, 2006). Some of the cultural changes that could provide evidence of the battle lost include changes in domestic architecture (i.e. from circular to multi-cellular rectilinear); the mode of agricultural production (introduction of the ard, or scratch plough, and thus a move to larger-scale extensification); copper production, food preparation and consumption technologies; and dress and burial practices (Peltenburg 1996; Knapp 2008; Frankel and Webb 2006). In terms of the island's cultural evolution and its level of similarity with the mainland traditions, the sliding scale would look parabolic, with the early Neolithic and Late Bronze Age more integrated into the broader interaction network and the late Neolithic and Chalcolithic displaying different levels of independence in between.

\section{Archaeobotany of Cyprus}

The introduction of flotation techniques in the early 1960s and their widespread application beginning in the 1970s is significant in the history of archaeobotany the world over (Streuver 1968; Hole et al. 1969; Helbaek 1969; van Zeist 1970; Jarman et al. 1972). In Cyprus, the recovery of plant remains from archaeological contexts began before the application of flotation, with charred plant material hand-picked during excavation at LBA Apliki (du Plat Taylor 1952; Kling et al. 2007). In 1974 flotation was conducted at Neolithic Dhali-Agridhi, followed shortly by Aceramic Neolithic Khirokitia-Vounoi and Cape Andreas-Kastros (Waines and Stanley-Price 1977; Stewart 1974; van Zeist 1981). Flotation enabled larger quantities of plant remains to be recovered, including both large and small taxa, increasing the likelihood of a better representation of a fuller set of charred plant remains, and enabling a wider set of research questions to be addressed. Standardisation of recovery and identification methods, including smaller mesh sizes, larger reference collections and widespread publication, meant that comparison of archaeobotanical data between periods, sites and regions was less limited by biases of differential recovery and identification (see also Colledge et al. 2004). 
On Cypriot excavations, the widespread application of flotation occurred more slowly than on the mainland Levant possibly as a result of numerous reports of poor preservation of charred macro-botanical remains, with archaeobotanists stating that the retrieval of plant remains from sites in Cypruswere too poor, and the archaeobotanical data too sparse, to study quantitatively (for summary and discussion of sites refer to Lucas 2014). This in turn inhibited both flotation efforts during excavation and regional and large-scale analyses of the data. While there is no doubt that preservation issues are partly to blame for the low densities of plant material recovered from Cypriot sites, the sample size and context-type sampled also play a part (Lucas 2014). The archaeobotanical record of Cyprus reflects the slow progression of social complexity and presumed low population densities throughout the Neolithic, Chalcolithic and Early and Middle Bronze Ages; with low population densities and small site-sizes, lower archaeobotanical retrieval is almost to be expected.

The unevenness of archaeobotanical retrieval and systematically floated and analysed data for the different cultural periods makes detailed inter-site analysis difficult (see Lucas 2014), especially for the underrepresented Pottery Neolithic and Bronze Age. Nevertheless, larger regional comparisons between Cyprus and the mainland Levant have shown regional and chronological patterns in the data (Lucas 2014). When the data for each cultural period is combined (i.e. 'binned', based on broad chronological and cultural groupings), broad diachronic comparisons are not only possible but fruitful (discussed below).

Of the three 'founder' cereal crops domesticated in the early Neolithic of the Near East, wild barley (Hordeum spontaneum), is the only one thought to be indigenous to Cyprus: currently there are no historical or present-day records for either wild einkorn (Triticum boeoticum) or emmer wheat (T. dicoccoides) (Christodoulou 1959; Holmboe 1914; Meikle 1985; Zohary and Hopf 2000). However, recent data, albeit limited, from Klimonos raises the possibility of wild emmer in Cyprus during the PPNA, although these could be introductions from the mainland rather than local wild populations (Vigne, Briois et al. 
2012; Vigne et al. 2017), suggesting movement of populations of emmer still undergoing domestication, that is, during the stage of incipient pre-domestication cultivation on the mainland (see phases in Fuller et al. 2018). A migration of farmers from the mainland during the Cypro-Early to Middle PPNB is well established (Peltenburg et al. 2000, 2003). By the late Pottery Neolithic, all founder crops, including flax (Zohary and Hopf 2000), and free-threshing wheat are present, though not at every site and not in large quantities (Colledge et al. 2004; Colledge and Conolly 2007; Peltenburg 2003; Lucas et al. 2012; Pares and Tengberg 2017). Taken together, this data indicates an increase in crop diversity over the course of the Neolithic, suggesting several sequential introductions of crop species. Based on current evidence, emmer wheat and barley could have been brought as early cultivars, morphologically wild near the start of the PPNA, c. 9500 BC, as indicated at Klimonos (Vigne et al. 2012). If so, then the additions of one-grained einkorn wheat and two-grained einkorn wheat were newly introduced to the island during the PPNB, between 8500 and 7500 BC (Peltenburg et al. 2003; Lucas et al. 2012; Asouti and Fuller 2013) - the era of entrenched pre-domestication cultivation on the mainland (Fuller et al. 2018). At this time these species were still undergoing domestication - that is, the evolution of domesticated morphology - on the mainland (Fuller et al. 2012, 2014; Arranz-Otegui et al. 2016), which implies that the trends to fixation of traits like nonshattering and larger grain size took place in parallel on Cyprus and on the mainland. It remains unclear to what extent this should be attributed to recurrent gene flow (i.e. frequent introductions from the mainland) or just parallel evolution under similar circumstances. Nevertheless, it is clear from lithic data, such as sickle blades, that Cyprus followed a very different trajectory to that followed by the Levant, suggesting that cultural contact, although perhaps frequent, did not determine local processes (e.g. Maeda et al. 2016). In this regard, parallelism seems plausible. What is more, metrical analysis of einkorn, in particular two-grained einkorn, indicates accelerated evolution of grain size increase on Cyprus, in contrast to slower mainland processes (Lucas et al. 2012). This certainly argues for a degree of isolation of the crop populations in Cyprus once they were introduced and suggests a few rather than recurrent crop transfers. 
Further, the evidence for the origins of the earliest farmers on Cyprus does not support one region of migration but shows similarities with sites across the Levant and southeast Anatolia (Lucas 2014; Colledge and Conolly 2007; Colledge et al. 2004; Murray 2003; Hansen 2001; Willcox 2003a). Thus what has been previously described as a 'Neolithic Crop Package' did not appear to move as a complete package; rather, certain elements of the early crop assemblage of the Levant were brought to different regions of Cyprus at different times in prehistory, beginning as early as the PPNA and diversifying over the course of the Neolithic (see also Colledge and Conolly 2007). There are a few major differences between the composition of crops recovered from sites in Cyprus and the mainland during the early PPN, including an absence of chickpea and rye, and insignificant presence of free-threshing wheat with only an infrequent appearance in later periods of the PPN (Hansen 2001; Willcox 2003a, p. 237). The limited and tentative evidence of free-threshing wheat during the late PPN of Cyprus comes from Dhali-Agridhi, where it is present in two samples (out of 99) (Steward 1974; see also Colledge and Conolly 2007), and from Khirokitia-Vounoi, where it is present in one sample (out of 131; Hansen 1994). However, more recently there is more substantial evidence of freethreshing wheat in samples from Khirokitia-Vounoi (Pares and Tengberg 2017). The evidence for staggered species-introductions after the initial introduction of farming to the island during the Late PPN includes six-row hulled barley (c. 6150 cal BC, Khirokitia), naked barley (c. 6550 cal BC, Dhali-Agridhi), free-threshing wheat (c. c. 6150 cal BC, Khirokitia-Voinoi), chickpea (c. 6550, Dhali-Agridhi), and flax (c. 8450, KissonergaMylouthkia); the fruit-tree species hackberry, olive, plum, pear and grape also appear in assemblages (see Lucas 2014 for chronology). Introductions during the subsequent Pottery Neolithic include rye, greater amounts of free-threshing wheat, more varieties of pulses (e.g. grass pea), and an increase in weeds associated with agriculture (Colledge and Conolly 2007, p. 61; Hansen 1991). There appears to be another group of crops introduced during the Bronze Age, with pomegranate, recovered from Kissonerga-Skalia (Thoma 2014), faba bean, citron and hazelnut (see Lucas 2014). The scattered nature of species introductions to the island has been used to argue for continued contact between the broader Near East and Mediterranean interaction spheres during prehistory (Lucas 2014). 
Zooarchaeology of Cyprus

As stated above, the zooarchaeological evidence from Cyprus suggests that the only mammalian fauna present on the island prior to human occupation are the Cypriot pygmy hippopotamus (Phanourios minutus) and the pygmy elephant (Elephas cypriotes) (Simmons 1999; Horwitz et al. 2004; Vigne 2011). The remaining fauna recovered from prehistoric archaeological contexts are the result of human migration and species translocation from the mainland Levant, beginning in the Akrotiri Phase (c. 10500 cal BC). During the contemporary mainland Natufian humans began to frequent the island, bringing with them stocks of wild boar (Sus scrofa) - populations that were undergoing some form of management and emergent domestication (Vigne et al. 2009, 2012). By the later phases of the Cypro-PPNB, all animal species representative of the later Cypriot animal repertoire were present, including animals exploited for their meat (and milk) (i.e. sheep, goat, pig, cattle, fallow deer) and those that likely were not (i.e. dog, fox, genet, cat and the house mouse) (Vigne et al. 2000, 2012; Horwitz et al. 2004; Peltenburg et al. 2003). Of significance are finds of cat associated with a human burial at Cypro-PPN Parekklisha-Shillourokambos (c. 7300-7200 BC), as well as evidence from Cypro-PPNA Ayios Tychonas-Klimonas. These finds are suggestive of early taming and potential domestication of the animal prior to the evidence for domestication in Egypt during the second millennium BC (Vigne et al. 2004, 2012).

Debate continues regarding the domestication status of the introduced species at time of translocation. The argument hinges on the relative significance of morphological (reduction in body size, bone density, and horn form: Horwitz et al. 2004) and nonmorphological (shift in age and sex ratios of culled animals, and increase in targeted species: Horwitz et al. 2004; Vigne 2011; Zeder 2008) domestication criteria. If more weight is given to morphological criteria, then there were multiple introductions of wild populations to the island (Horwitz et al. 2004). If more weight is placed on nonmorphological criteria, then the animals that were introduced were under management on the mainland as early as 11,400 years ago, and were undergoing domestication when 
transported. Thus, the evidence from Cyprus of goat, sheep and cattle is suggestive of multiple introductions of different lineages of pre-domesticated species transported to the island beginning in the tenth millennium BC (Clarke et al. 2007; Vigne et al. 2009; Vigne 2011). The earliest phases at Parekklisha-Shillourokambos (Cypro-PPNA) suggest hunting of goat, with a move towards intensive exploitation in the middle phases of occupation with non-morphological change (i.e. based on culling profiles) suggestive of domestication by the later phases of occupation (Vigne 2011). However, hunting of both pigs and caprines accounts for an estimated $55 \%$ of the meat supply in the early phases, suggesting that animal husbandry was secondary to hunting (Vigne et al. 2003). Herding intensifies into the Cypro-PPNB, later Neolithic and Chalcolithic periods but the continued hunting of feral populations is highly likely (Croft 1991). As hunting of feral populations ends, the herding of caprines intensifies and continues into the Bronze Age. By the Late Bronze Age caprines dominate archaeozoological assemblages (see Spigelman 2006). After a long hiatus that begins in the Khirokitian Phase cattle are re-introduced (along with the introduction of donkey) in the early Bronze Age (Croft 1996; Horwitz et al. 2004; Vigne et al. 2000; Simmons 1998; Croft 1991; Şevketoğlu 2000).

In addition to the continued practice of hunting feral caprine and pig populations throughout the Neolithic and Chalcolithic, the hunting of managed populations of fallow deer was a practice unique to the island (Croft 1991). The story of the exploitation of fallow deer involves an introduction during the early Neolithic, a rise in importance during the Pottery Neolithic and Early Chalcolithic - when it becomes the primary meat source for a majority of sites - and a slow decrease in importance from the Middle Chalcolithic, until the practice all but disappears in the Late Bronze Age (Croft 1991; Legge 1982; Vigne and Buitenhius 1999; Peltenburg et al. 2000; Vigne et al. 2000; Horwitz et al. 2004; Spigelman 2006). As evidence of the domestication of deer anywhere is lacking, it can be assumed that the species was introduced to the island by humans for the purpose of stocking the landscape with a 'free-living, huntable animal' (Croft 1991, 2002). Further, Croft (2002) argues, based on the relative importance to diet, that the hunting of deer would have been conducted in a controlled, sustainable way within a system of game management'. We should emphasise that we are interested here in human behaviour and 
what that behaviour can tell us about the integrated agricultural system and level of dependence on that agroecosystem. Thus, we are not necessarily concerned with whether experiments in deer domestication took place or at what level the game were managed, but rather that they were hunted and how hunting activities tie into seasonality and scheduling of labour with regards to crop-agriculture.

Although deer makes up a large proportion of faunal remains at most sites, there is intersite variation. Croft (1991) suggests that the success of large, island-wide deer populations and the inter-site variation are a result of economy, ecology, demography, and the animal's grazing behaviour. He argues that the ecological backdrop of the past would have been moister with more woodlands (i.e. more deciduous tree species), and as a result would have provided a more diverse browsing vegetation. Given the lack of competition from large mammalian herbivores, their ability to thrive in a variety of habitats (open grasslands to dense woodland), and lower human populations during the early Neolithic, the fallow deer populations would have easily populated most of the island (below 1000 m elevation) within a couple of centuries (Croft 1991; see also Frankel et al. 2013). As for inter-site variation, Croft (1991) suggests Neolithic sites with atypically large populations, such as Khirokitia-Vounoi and Kalavasos-Tenta, would not have relied as much on hunting because it could not have easily supported the population (see also Croft 2005). This has also been suggested for the Middle to late Chalcolithic transition at Kissonerga-Mosphilia (Croft 1998). In the subsequent Philia (i.e. onset of the Bronze Age, Period 5) the region sees a reduction of human population alongside a continued reliance on deer (Croft 1998). This is not necessarily island-wide, as the evidence from MarkiAlonia suggests a decline in deer hunting but with the addition of cattle and increased populations (1996). Thus, the inter-site variations in proportions of deer, caprine and pig might relate to differences in site size and inferred population as well as local environmental and social factors. Moreover, when sites are clustered by region (i.e. the coastal belt; the Kyrenia or northern range; the Troödos or southern range; and the central plain) and cultural chronology, the chronology offers the best prediction on deer ratios, that is, the percentages of deer are highest in the Neolithic and Chalcolithic periods. In addition to Khirokitia-Vounoi and Kalavasos-Tenta, we see sites dating to the Middle 
Chalcolithic onwards, particularly in the Ktima lowlands of western Cyprus, demonstrating population expansion which would have provided a motive for the reduction in hunting and investment in domestic stock (that is, caprines and pig) (Croft 1991, 1998). It is also at this time that domestic pigs increase alongside a decrease in evidence for the hunting of feral pig populations (Croft 1991). Colledge $(1980,1981)$ suggests feral pigs would have created problems for crop-agriculture, and as a result Croft (1991) attributes the increase in domestic pig stock at this time to strategies aimed at reducing feral pig populations in the region.

The island appears to differ from the surrounding regions not only in its unique hunting culture but also in its delay, or rather, reversal in incorporating secondary animal products (i.e. dairy, wool and traction), or what Vigne and Helmer (2007) term ante mortem products (life-time products, in contrast to the final product, i.e. meat). There is evidence of the use of an ante mortem product (milk) in the early Neolithic (Vigne et al. 2003), but it is lacking from the late Neolithic and Chalcolithic periods and limited in the Early and Middle Bronze Age. It appears that ante mortem products in Cyprus are not fully exploited until the Late Bronze Age (see Spigelman 2006). Current research on culling profiles (caprines and bovids) (Helmer and Vigne 2007; Helmer et al. 2007), stable isotopes (Balasse and Tresset 2002), lipid residue analysis from ceramic vessels (Evershed et al. 2008), and human palaeogenetic data (Burger et al. 2007) places dairying millennia earlier than originally proposed, as early as the ninth millennium BP in Anatolia (Evershed et al. 2008); the relative importance to human diet is still uncertain (Vigne et al. 2015).

The earliest evidence of milk exploitation from Cyprus comes from Shillourokambos (7900-7600 cal. BC). Vigne and colleagues $(2003,2015)$ propose the use of sheep milk in the earliest phase, with a transition to goat milk by the latest phase (7400-7000 cal. $\mathrm{BC}$ ). This contrasts with what has been argued for Kissonerga-Mosphilia, where meat is the main objective of caprine husbandry, rather than any ante mortem product including milk (Croft 2002, 2003). The lack of evidence for milk exploitation continues into the Chalcolithic, at least in the southwest at Kissonerga-Mosphilia and Chalcolithic Kissonerga-Mylouthkia (Croft 1998). The use of ante mortem products possibly begins 
again in the Early and Middle Bronze Age, but not as a primary resource. Croft (1996) argues that although the inhabitants of Bronze Age Marki-Alonia would not have ignored the dairy and wool potential of caprines, the evidence suggests they were kept more for their meat than for any ante mortem product. It is suggested that it is only during the Late Bronze Age that the use of ante mortem animal products intensify (see Croft 1996, p. 271; Falconer and Fall 2013a; Manning 1993; Knapp 1990; Spigelman 2006). The slow adoption of these products is unusual; however, cattle were only re-introduced to the island in the early Bronze Age. Thus, the introduction of cattle can be viewed as the beginning of a major shift in agricultural, and perhaps subsistence, practices. Croft states that cattle 'lay at the heart' of the secondary products transformation, as they would have provided 'more milk than caprines, more traction than donkeys, and more dung (for fuel, fertilizer and constructional purposes) than all of the other animals and humans combined' (Croft 1996, p. 271). However, cattle do not become dominant in the subsequent Late Bronze Age, caprines do (Spigelman 2006). The shift to the ante mortem products of caprines can be explained by the introduction of new breeds that were better milk and wool producers (Webb et al. 2009). Spigelman (2006) summarizes the shift in strategies during the Middle-Late Bronze Age transition and argues that the decrease in hunting and species diversity, and the move towards a focus on ante mortem caprine products (milk and wool), can be seen as a shift in risk management strategies, extending social networks and strengthening local identities.

Recent human isotope analysis from several sites in Cyprus possibly supports these developments. The sites with published results are: Neolithic Khirokitia (Lange-Badre and le Mort 1998); Middle Bronze Age Erimi Laonin tou Porakou ( $N=5)$ (Sciré Calabrisotto 2017a); Chalcolithic Souskiou-Laona (N=1); Neolithic-Chalcolithic KissonergaMylouthkia (data not sufficient); Chalcolithic Kalavasos-Kokkinoya (data not sufficient); Early Bronze Age Psematismenos-Trelloukkas ( $\mathrm{N}=2)$; and Early-Middle Bronze Age Karmi-Paleolona (data not sufficient) (Goude et al. 2018). Although the data is limited and the authors exercise caution in interpretations, it appears the early Cypriot diet was mainly terrestrial (meat/milk and $\mathrm{C}_{3}$ plants), with variable animal protein intake according to individual and without a marine contribution (Sciré Calabrisotto 2017a; Lange-Badre and 
le Mort 1998; Goude et al. 2018). These results are not surprising and provide support to both the archaeobotanical and zooarchaeological data. With regards to the plant data, the cereal, pulse and fruit taxa characteristic of prehistoric Cypriot assemblages are $\mathrm{C}_{3}$ plants (Goude et al. 2019). Also, not surprising is the apparent shift in nitrogen stable isotope values from the Chalcolithic $(\mathrm{N}=1)$ to the Bronze Age, with the Bronze Age samples ( $N=2)$ displaying higher ratios (Goude et al. 2018). According to Goude et al. (2018), this shift could suggest that either the Chalcolithic individual consumed more legumes - or more animals that were fed legumes - or that the Bronze Age individuals consumed more animal proteins and possibly animals that had not yet weaned. Legumes are characteristic of small-scale intensive agriculture and we see an increase in their presence during the Cypriot Neolithic and Chalcolithic periods (Lucas 2014; discussed by Lentini 2009; see also Fig. 2b). Thus, the higher ratios of nitrogen stable isotopes for the Chalcolithic individual are likely a result of legume consumption, rather than of the consumption of animals fed with legumes, as the faunal data suggests a high contribution of deer meat. As for the Bronze Age individuals, the lower nitrogen ratios could be a signal of the move towards caprine milk, which provides support for the timing of ante mortem products in prehistoric Cyprus. In summary, it is clear that the faunal record of early Cyprus is complex and of a mosaic nature, with different species translocated to the island at different stages of management and domestication, and that throughout prehistory Cyprus appears to practise a unique hunting and animal-management strategy that does not follow the same pathway to an integrated agro-pastoral system, including the incorporation of ante mortem animal products, as seen in the surrounding regions.

\section{Materials and Methods}

Plant Data

The material used in this research comes from previously published data from mainland Levantine and Cypriot sites. For sites dated from 11000 to 5000 cal BC, refer to Maeda and colleagues (2016, S5); for sites dated after 5000 cal BC, see Lucas (2014) and Riehl and Kümmel (2005, with references); and for sites dated from 8500 to 1370 cal BC in 
Cyprus, refer to Online Resource 1. Only sites in Cyprus with charred macro-botanical data recovered by flotation and reported whole counts are included in this study. In order to address the importance of cereals in the diet and to infer scale of agricultural reliance we have taken a percentage of the total number of cereal specimens - including grains and chaff of barley (Hordeum spontaneum and H. vulgare), wheats (Triticum spp.), and rye (Secale spp.), whether recorded as wild or domestic - out of all counted charred plant remains from 21 sites (34 chronological phases) in Cyprus (Table 1). This is the total number of identifiable specimens of all cereals summed (including grains and chaff); we did not attempt to estimate the number of specimens by combining chaff and grain from the same species. This method was used recently by Maeda and colleagues (2016), who outline its potential limitations, including the differences in chaff-to-grain ratios across different cereals; variations in the sampling, sorting and reporting strategies of different archaeobotanists; and differential patterns of crop-processing waste and preservation. It was assumed that biases 'balance out' when all cereal specimens are totalled. We follow the methodology used previously and take a simple summed frequency approach, as this requires the fewest assumptions. The 'other crops' category includes the total number of specimens of all pulse taxa (Pisum, Lens, Lathyrus, Cicer, Vicia ervilia or V. faba) and flax combined (Linum spp. and Linum usitatissimum), with the 'total crops' being a total of cereals and other crops combined. We recognize the difficulty in determining which wild species were collected by humans for consumption, so we focus our analysis on the cereals and other known crops. Nonetheless, we categorize the remaining taxa. For the potential wild food resources, we have determined the likelihood of collection for the purpose of human consumption based on previous research (see Fuller et al. 2018; Lucas and Fuller 2018). We have grouped all nutlets - which have dry, starchy, easily storable seeds - into a single category, comprising the total number of specimens identified as nutlets, which we take include identification of various knotweeds, docks, sorrels or clubrushes (Polygonum, Rumex, Scirpus/Bolboschoenus and Schoenus). We have grouped fruits and nuts together as they have similar seasonality of availability, with collection time in late summer and early autumn. The nuts in this category include almonds, pine nuts, terbinth/mastic nuts, and acorns (Amygdalus, Pinus, Pistacia, and Quercus). The fruits include the total number of specimens identified to the following groups: olives, plums, 
pomegranites, apples or pears, capers, hackberries, jujubes and grapes ((Olea, Prunus [sensu stricto], Punica, Pyrus/Malus, Capparis, Celtis, Ziziphus, and Vitis), with grapes (Vitis) and olives (Olea) comprising an additional group called 'cash crops'. Fig (Ficus carica) is treated separately because there are several ways it might be overrepresented in archaeological samples. First, there are hundreds of seeds per fruit, potentially leading to a larger number of seeds preserved and later recovered. Second, fig seeds are light and thus when charred float well, increasing the chance of recovery during flotation (i.e. archaeobotanical recovery). Third, the use of figs as fodder has been documented ethnographically (Forbes 1998; see also Valamoti 2004), and experimental evidence demonstrates that they preserve well through the digestive tracts of goats (Valamoti and Charles 2005), increasing their recovery in samples resulting from the burning of dung for fuel. Thus, figs might provide insight into the timing of a more integrated agroecosystem in Cyprus (discussed below).

\section{Animal Data}

The animal data used in this research comes from previously published reports from Cyprus (Online Resource 2). The percentages reported and used in this analysis are based on estimating the relative contribution to the meat supply for each taxon of fallow deer, pig and caprine from 42 phases in Cyprus. This method was chosen over the percentage of the total faunal assemblage because we are interested in an estimation of the overall contribution of each taxon to the prehistoric Cypriot meat diet, although we recognize this is extremely difficult to determine. For full details on the calculation used to estimate the meat yields and the percentage of contributions to meat supply for deer, pig and caprines refer to Croft (1991).

\section{Chronology}

There are not enough sites and phases that have sufficient animal, plant and radiocarbon data. Since our aim is to look at long term trends in the data, we have chosen to 'bin' the data according to median calibrated date ranges from each site, where we have taken 
the average of the relative proportions for each bin assigned by broad cultural and chronological phase (for radiocarbon dates for sites located in Cyprus refer to Lucas 2014; for mainland sites with radiocarbon dates from sites dates up to 5000 cal BC refer to Maeda et al. 2016). Thus, the median calibrated date ranges for broad cultural phases we use here are as follows: Cypro-PPNB (7750 cal BC); Khirokitian (6100 cal BC); Pottery Neolithic (4300 cal BC); Chalcolithic (3150 cal BC); Bronze Age (1850 cal BC). Radiocarbon dates have been re-calibrated using OxCal v3.10, with the IntCal09 calibration curve (Bronk Ramsey 2006; Reimer et al. 2004). All chronological determinations are expressed in calibrated years BC. The median calibrated date is based on a point estimate age within 1-sigma of the summed probability (one standard deviation), which will be used in this discussion to assess an estimated chronology for botanical and faunal assemblages.

\section{Results and Discussion}

Against the Grain: Trends in Crop Dependence from the Early Neolithic

Our study demonstrates the delayed transition to full agricultural reliance or to DC (domestication cultivation), as described above, and maintenance of a diverse mixedsubsistence base or prolonged period of intermediate economies in Cyprus. Figure $2 a$ is a scattergram plot of the percentage of cereals from Cypriot sites dated from the Neolithic, Chalcolithic and Bronze Age. This figure shows an overall decline in the percentage of cereals from the Cypro-PPNB to the end of the Chalcolithic, with the relative proportions of cereals at their lowest during the Pottery Neolithic and Chalcolithic. This is generally in contrast to patterns of the mainland Near East, in which the proportions of cereals found in site assemblages tended to increase from the PPNA; cereal-poor sites ( $<20 \%$ cereal remains) had disappeared from the Levant by 6000 BC (see Maeda et al. 2016: Fig. 3; Fuller et al. 2018).

In the subsequent Cypriot Bronze Age we see a slight increase in the relative proportions of cereals, but these barely return to Cypro-PPNB levels, illustrating a similar parabola to the one described above for the island's prehistoric cultural chronology and history. 
Without more systematically floated and analysed archaeobotanical data from the Bronze Age, we can only assume that the general trend in agricultural reliance significantly increases by the Late Bronze Age, when newly urbanized and more densely-populated Cyprus is fully situated within the broader Mediterranean trade network. Also highlighted is a pattern of increasing percentages of fruits, particularly 'cash crops' (olive, grape) and fig beginning in the Chalcolithic (Fig. 2b). The pattern for cereals, fruits, nuts and nutlets is in contrast to what has been reported for the mainland Levant, where the transition to agriculturally reliant economies is relatively slow but there is an increase in cereals over time, corresponding to a decrease in wild plant resources, with the percentage of cereals reaching over $50 \%$ by c. 6000 cal. BC (see Maeda et al. 2016; Fuller et al. 2018) and above $90 \%$ by c. 4000 cal BC (Fig. 2c). While cultivated fruits, like grape, olive and fig, are present on the mainland they are a far less obvious part of the overall composition of archaeobotanical assemblages (see Fuller and Stevens 2019). Thus Cyprus follows its own trajectory, distinct from the grain-centric Near Eastern mainland.

The patterns in the plant data mirror larger trends in the archaeology of Cyprus during the Neolithic, Chalcolithic and Bronze Age, where the data suggests close links with the mainland Levant during the Cypro-PPNB, with a departure from the mainland by the Khirokitian-and a return to the broader Near Eastern and Anatolian interaction sphere only at the end of the Late Chalcolithic, 2500 cal. BC (see Bolger 2013; Peltenburg et al. 2001; McCartney 2005; McCartney et al. 2006; Wasse 2007). Similarities between the mainland Levant and Cyprus in the reliance on cereal crops is strongest in the initial phases of island colonization by mainland farming communities. Thereafter, during what has been described as the colonization and consolidation phase (Peltenburg 2003; Bolger 2013), Cyprus diverges from the mainland trajectory towards a more diverse and grainpoor subsistence. With a rise in long-lived perennial crops, the 'cash crop' trees and vines, increasing reliance on cereals follows. This may reflect both the need for cash-crop farming populations to be supported by surplus grain production, and the gradual replacement of wild woodlands with planted orchards and vineyards. Further, the adoption and increasing production of tree crops and vines is part of increased engagement in the Early Bronze Age trade networks of the eastern Mediterranean. 
Evidence from the Levant indicates the increasing importance of olive, grape and date production (Weiss 2015; Fuller and Stevens 2019), as well as morphological indicators of olive domestication by the Early Bronze Age (e.g. Dighton et al. 2017; Fuller 2018).

Another distinctive aspect of early Cypriot farming tradition is apparent from the types of cereals recovered from sites dated to the Neolithic, Chalcolithic, and Bronze Age. Interestingly, the continued preference for glume wheats until the Cypriot LBA suggests a possible social preference for crops that can be stored longer (i.e. in their glumes) and processed at a small-scale household level. It has been argued that this cereal preference corresponds with the lack of demographic pressure and delayed increase in social complexity on the island compared to contemporary cultures on the mainland (Lucas 2014).

The Great Cypriot Hunt: Trends in Animal Management Strategies Beginning in the Early Neolithic

Our study supports what has been demonstrated previously, namely that Cyprus maintained a significant reliance on fallow deer throughout the Neolithic and the Early and Middle Chalcolithic. The data shows increasing reliance on deer, with a noticeable decline from c. 3000 cal BC, beginning in the Late Chalcolithic (Fig. 2d). As expected, the corresponding reliance on both pig and caprine are lower from the late Neolithic onwards. The data demonstrates a fluctuating reliance on pig, with a decline in relative proportions after the initial colonization phase (Cypro-PPNB), followed by a peak low during the Pottery Neolithic, a gradual increase during the Chalcolithic, and again a decline leading up to the Bronze Age, corresponding to an increase in caprines from the late Chalcolithic onward (Fig. 2e), which can be tied to the beginnings of caprine ante mortem products. The data suggests that during the Neolithic there was greater variation between sites in the relative contributions of deer, pig and caprine.

Comparing Trends of Cereals and Animals 
The results presented here illustrate parallels in the archaeobotanical and faunal data (Fig. 3). In particular, the relationship between the estimated relative contributions to the meat supply of pig and the relative proportions of cereals. The data demonstrates that pigs and cereals are highest during the early Neolithic - when the island shows the most similarities with the mainland Levant - and decrease over time, especially during the late Neolithic and the Early and Middle Chalcolithic. There is a slight rise in both pigs and cereals from c. 4500-3000 cal. BC, followed by a decline in the percentage of pigs while cereals continue to rise. The fluctuations in importance of both pigs and cereals corresponds to an increase in a distinct Cypriot cultural signature throughout the later Neolithic and Chalcolithic. This is in opposition to the pattern illustrated for deer, caprines and cash crops (fruits), where the data suggests a correlation in decreasing importance of deer and the development of both cash crops and secondary caprine products. Thus, there is an overall increase over time in hunting of deer, but with a drop after c. $3000 \mathrm{cal}$ $\mathrm{BC}$, when the relative proportions of cereals, cash crops and caprines increase, perhaps indicating a more integrated agricultural system that included cash crops, cereal crop agriculture and milk and wool production.

The patterns in the data are suggestive of an economic dichotomy, where we see a strong correlation between hunting of managed populations of fallow deer and reduced agricultural reliance, that is, a reduction in the percentage of cereals, versus caprine and pig management alongside increasing agricultural reliance with cereals and cash crops dominating. At the time of the arrival of farming groups to Cyprus during the Cypro-PPNB, the island shows strong similarities, not just in material culture and architecture, but also in the mode of agriculture practised (small-scale intensive) and the scale of agricultural reliance - that is, the majority of sites are classified as either foraging-dominant $(<20 \%$ cereal crops) or intermediate or mixed subsistence $(>20-<80 \%$ cereal crops) (Fuller et al. 2018, table 1). In the subsequent Khirokitian, and more so in the late Neolithic, the archaeobiological data presented here is suggestive of a separation from the Levantine mainland trajectory, which shows increasing dependence on cereal agriculture, with assemblages that can be considered agricultural ( $>80 \%$ of crop remains) frequent only after 7000 BC (Fuller et al. 2018). This pattern persists until the Late Chalcolithic when 
we finally see increasing percentages of crops in Cyprus coupled with decreasing importance of the Cypriot hunting culture (deer and feral pig populations). It is at the beginning of the Late Chalcolithic that the dynamics between plants and animals change, hunting begins to decline, and cash crops and caprine husbandry begin to rise.

It is also during the Late Chalcolithic that we see possible indications of experimentation with the scheduling of both deer hunting and cereal agriculture. The seasonality and scheduling of labour for hunting and cereal cultivation were in direct competition, as the winter cereals of Near Eastern agriculture were typically sown in the autumn and harvested in the spring and early summer, and the hunting of deer in Cyprus likely occurred between late winter, spring and early summer (Frankel et al. 2013), that is, during the cultivation season. Support for hunting seasonality comes from a seasonally occupied hunting camp site, Chalcolithic Kokkinorotsos, where Frankel and colleagues (2013) argue for hunting, not just of deer but caprine too, during the warmer months between the close of winter and the end of summer. Further evidence for the seasonality of sowing and harvesting times for cereal crops is provided by the presence of arable weeds recovered from archaeobotanical samples. A distribution of the flowering/fruiting times shows that most arable weeds harvested along with the cereals and recovered from archaeological sites dated to the PPN to Bronze Age flower between March and May (Lucas 2014). However, there is a shift in the distribution over time, with more latesummer-flowering weeds in the Chalcolithic and Bronze Age samples than in the Neolithic samples. This pattern suggests an attempt to perhaps shift the harvest to later in the summer (Lucas 2014), in an effort to balance deer hunting with increasing demands for greater agricultural surplus - an agricultural reliance that perhaps reflects an adaptation to urbanization and population increase. However, dynamics relating to the demand for copper resources become more marked in the Bronze Age and we see a shift toward site locations that are closer to copper resources but located on poorer soils, with extensification practices facilitated only by the re-introduction of cattle and plough- (ard-) based agriculture. Although the choice to locate closer to copper resources does not necessarily pull people from deer populations, the seasonality conflicts force people towards a more agriculturally reliant subsistence strategy, with a shift towards greater 
reliance on extensive agricultural practices, more livestock integration, and eventually ante mortem products. With an increase in caprines and dairying we can assume a more culturally integrated agroecosystem characteristic of Near Eastern agriculture. This pattern could also explain the increase in cereals, figs (used as fodder), and the burning of dung as fuel - a pattern we see beginning in the Bronze Age.

We argue that the delayed reliance on cereal-based agriculture and extensification practices (only evident beginning in the Cypriot Chalcolithic), alongside the continued importance of deer hunting, was not an indication of cultural isolation or a lack of knowledge of the economy of surrounding regions but was a matter of choice (see also Bolger 2013). With regards to animal and plant resources, the people of Cyprus were aware of mainland agricultural systems, evidenced by multiple staggered introductions of a variety of cereal, pulse, fruit and animal species, and these networks were likely a twoway street of goods and people (McCartney 2017; see also Lucas 2014). The communities of early Cyprus chose to practice a mixed subsistence strategy that involved low-level food production (i.e. crop agriculture, livestock management and wild plant gathering), and maintained what appears to be a strong hunting culture. This mixed subsistence strategy continued here much longer than on the mainland, and can be argued to have been an effective adaptive strategy that worked for the island's population and complexity levels, and also a risk-management strategy in the face of periodic droughts that would have threatened crop-agriculture. The communities were then able to adapt to changing social pressures by modifying their relationship with cereal cultivation and arboriculture, and focus more on caprine husbandry and less on deer hunting when they needed to, either for internal demographic and social reasons (demands for copper and cash crops) or when this made most sense in relation to outside influences and interactions. This protracted dependence on agricultural production may be symptomatic of a recurrent process of crop assemblages being tested when they first spread and often suffering some attrition or even abandonment due to differences in local social and environmental conditions. 
The instability of crop packages and their observed breakdown as they spread from their centres of origin, both westward into Europe and east towards India, has been discussed previously (McClatchie et al. 2014; Fuller and Lucas 2017). In some cases it appears to be associated with an initial agricultural boom phase, followed by a bust, which may have involved population declines and degrees of agricultural abandonment (e.g. Shennan et al. 2013; Whitehouse et al. 2014; Stevens and Fuller 2015; Bevan et al. 2017). Even though Cyprus was the location of the first targeted migration of farming populations from the Levant, and it is geographically close to the mainland and thus climatically similar, quantitative evidence for a reduced crop package and reduced reliance on crops raises the possibility of similar decline after the initial spread, coupled with the lack of demographic pressure on the island until the Late Bronze Age, which enabled the persistence of a light farming/cultivating-hunting strategy (i.e. intermediate or mixed subsistence economy) that was established early in the island's PPN. Thus, what Wasse (2007) had suggested for agricultural 'de-intensification' (defined here as a reduced scale of dependence on crops, as opposed to mode of the agricultural system in terms of labour input per unit of land, intensive versus extensive) in the Late Neolithic and Chalcolithic has been supported here quantitatively over the longue durée with an integration of the plant and animal data.

\section{Conclusions}

The integration of archaeobotanical and zooarchaeological data from prehistoric Cyprus (c. 8800 to $1300 \mathrm{BC}$ ) provides a coherent picture of subsistence change and land use on an island. After initial colonization by early farmers from the mainland, the inhabitants of Cyprus followed a mixed subsistence strategy that included less toil at cereal production and livestock keeping, and took advantage of hunting managed populations of deer, and gathering. A correlation between the hunting of fallow deer and gathering of wild plant resources has been proposed previously for prehistoric Cyprus. Our results illustrate alternating correlations between cereal agriculture and animal husbandry on the one hand and hunting of fallow deer and gathering on the other. Only in the Bronze Age does deer hunting decrease alongside perennial land use for 'cash crop' trees and vines and 
secondary animal products (i.e. ante mortem products), evidenced by archaeobotanical data from Politiko-Troullia (Falconer and Fall 2013b; Kling and Fall 2010). This indicates that orchards and vineyards had become the new woodlands and may have even impinged on land previously devoted to cereals and pig husbandry. The integration of data provides insight into a non-linear transition to agricultural reliance, which included both a pulling back from agriculture and a later move towards perennial land use for fruit crops that could be commodities for trade. The fluidity of subsistence strategies on Cyprus indicates that the island did not inevitably slide towards cereal agriculture as a consequence of either later Neolithic population expansion or climate change, but rather that the population was involved in a set of dynamic processes in which local resource availability, risk management, cultural choice, emergent social complexity, and engagement in a larger world system all played a part.

\section{Acknowledgements}

Research for this paper was in part supported by the Comparative Pathways to Agriculture research project (ComPAg), funded by a European Research Council advanced investigator grant (no. 323842), 2013-2018. The plant data from sites located in the mainland comes from two separate mainland databases compiled by Sue Colledge (Colledge et al. 2004) and Simone Riehl (Riehl and Kümmel 2005), and generously amalgamated by Sue Colledge. We also thank the anonymous reviewers for their helpful comments.

\section{References}

Ammerman, A., Flourentzos, P., McCartney, C., Noller, J., \& Sorabji, D. (2008). Third report on early sites on Cyprus. Report of the Department of Antiquities, Cyprus, 1-32.

Bar-Yosef, O. (2001). From sedentary foragers to village hierarchies: The emergence of social institutions. Proceedings of the British Academy, 110, 1-38. 
Balasse M., \& Tresset, A. (2002). Early weaning of Neolithic domestic cattle (Bercy, France) revealed by intra-tooth variation in nitrogen isotope ratios. Journal of Archaeological Science 29, 853-859.

Bevan, A., Colledge, S., Fuller, D., Fyfe, R., Shennan, S. \& Stevens, C. (2017). Holocene fluctuations in human population demonstrate repeated links to food production and climate. Proceedings of the National Academy of Sciences, 114(49), E10524-E10531.

Bogaard, A. (2005). 'Garden agriculture' and the nature of early farming in Europe and the Near East. World Archaeology, 372, 177-196.

Bogaard, A. (2004). Neolithic farming in central Europe: An archaeobotanical study of crop husbandry practices. London: Routledge, Taylor \& Francis Group.

Bogaard, A., Fraser, R., Heaton, T. H., Wallace, M., Vaiglova, P., Charles, M., et al. (2013). Crop manuring and intensive land management by Europe's first farmers. Proceedings of the National Academy of Sciences, 110(31), 12589-12594.

Bogaard, A., Styring, A., Mohammed, A., Hmimsa, Y., Green, L., Stroud, E., et al. (2016). From traditional farming in Morocco to early urban agroecology in northern Mesopotamia: Combining present-day arable weed surveys and crop isotope analysis to reconstruct past agrosystems in (semi-)arid regions. Environmental Archaeology. doi:10.1080/14614103.2016.1261217.

Bolger, D. (2013). A matter of choice: Cypriot interactions with the Levantine mainland during the late 4th-3rd millennium BC. Levant, 45(1), 1-18.

Bronk Ramsey, C., Buck, C. E., Manning, S. W., Reimer, P., \& van der Plicht, H. (2006). Developments for radiocarbon calibration for archaeology. Antiquity, 80(310), 783-798. 
Broodbank, C. (2000). An island archaeology of the early Cyclades. New York: Cambridge University Press.

Burger, J., Kirchner, M. Bramanti, B., Haak, W., \& Thomas, M. G. (2007). Absence of the lactase-persistence-associated allele in early Neolithic Europeans. Proceedings of the National Academy of Sciences 104(10), 3736-3741.

Button, S. (2010). Resource stress and subsistence practice in early prehistoric Cyprus. Unpublished PhD Dissertation. University of Michigan.

Christodoulou, D. (1959). The world land use survey: Regional monograph No. 2. In D. L. Stamp (Ed.), The evolution of the rural land use pattern in Cyprus. Cornwall, England: Geographical Publications Limited.

Clarke, J. (2007). Site diversity in Cyprus in the late $5^{\text {th }}$ millennium cal. BC: Evidence from Kalavasos-Kokkinoyia. Levant, 39, 13-26.

Colledge, S. (1980). Plant species from Kissonerga Mylouthkia Feature 16.3. Appendix I, pp. 18-20. In E. J. Peltenburg (Ed.), Lemba Archaeological Project, Cyprus 1978: Preliminary report. Levant, 12, 1-21.

Colledge, S. (1981). Kissonerga Mylouthkia 1979: Palaeobotanical report. Appendix 4, p. 47. In E. J. Peltenburg, Lemba Archaeological Project, Cyprus, 1979: Preliminary Report. Levant 13, 28-50.

Colledge, S. (1998). Identifying pre-domestication cultivation using multivariate analysis. In A. B. Damania., J. Valkoun, G. Willcox, \& C. O. Qualset (Eds.), The origins of agriculture and crop domestication (pp. 107-123). Aleppo, Syria: ICARDA.

Colledge, S. (2002). Identifying pre-domestication cultivation in the archaeobotanical record using multivariate analysis: Presenting the case for quantification. In R. T. J. 
Cappers \& S. Bottema (Eds.), The dawn of farming in the Near East (pp. 141-152). Berlin: ex Oriente.

Colledge, S., \& Conolly, J. (2007). A review and synthesis of the evidence for the origins of farming on Cyprus and Crete. In S. Colledge \& J. Conolly (Eds.), The origins and spread of domestic plants in Southwest Asia and Europe (pp. 53-74). Walnut Creek: Left Coast Press.

Colledge, S., Conolly, J., \& Shennan, S. (2004). Archaeobotanical evidence for the spread of farming in the eastern Mediterranean. Current Anthropology, 45, S35-S58.

Constantinou, G. (1982). Geological features and ancient exploitation of the cupriferous sulphide ore bodies of Cyprus. In J. D. Muhly, R. Maddin \& V. Karageorghis (Eds.), Early metallurgy in Cyprus, 4000-500 BC (pp. 13-24). Nicosia: Pierides Foundation.

Croft, P. W. (1991). Man and beast in Chalcolithic Cyprus. Bulletin of the American Schools of Oriental Research, 282/283, 63-79.

Croft, P. W. (1996) Animal remains from Marki-Alonia. In Frankel, D., \& Webb, J., Marki Alonia: An Early and Middle Bronze Age town in Cyprus. Excavations 1990-1994 (SIMA 123:1) (pp 217-222). Jonsered: Paul Åströms Förlag.

Croft, P. W. (1998). Animal Remains: Synopsis. In Peltenburg, E. J. (Ed.), Lemba Archaeological Project. Volume II. 1A: Excavations at Kissonerga-Mosphilia, 1979-1999 (pp. 215-223). Sävedalen: Paul Åströms Förlag.

Croft, P. W. (2002). Game management in early prehistoric Cyprus. Zeitschrift für Jagdwissenschaft, 48(1), 172-179. 
Croft, P. W. (2003). The animal remains. In Peltenburg, E. J. (Ed.), The colonisation and settlement of Cyprus: Investigations at Kissonerga-Mylouthkia 1976-1996 (pp. 59-71). Sävedalen: Paul Åströms Förlag.

Croft, P. W. (2003). Mammalian fauna. In Todd, I. A. (Ed), Vasilikos Valley Project 7: Excavations at Kalavasos-Tenta. Volume II. Studies in Mediterranean Archaeology, 71, 342-361.

du Plat Taylor, J. (1952). A Late Bronze Age settlement at Apliki, Cyprus. The Antiquaries Journal, 32, 133-167.

Evershed, R. P. (2008). Experimental approaches to the interpretation of absorbed organic residues in archaeological ceramics. World Archaeology, 40(1), 26-47.

Falconer, S. E., \& Fall, P. L. (2013a). Household and community behavior at Bronze Age Politiko-Troullia, Cyprus. Journal of Field Archaeology, 38(2), 101-119.

Falconer, S. E., Fall, P. L. (2013b). Agricultural economies and pyrotechnologies in Bronze Age Jordan and Cyprus. In Frankel, D., Lawrence, S., \& Webb, J. (Eds.), Archaeology in environment and technology: Intersections and transformations. New York: Routledge.

Frankel, D., \& Webb, J. (1996). Marki Alonia: An Early and Middle Bronze Age town in Cyprus: Excavations 1990-1994. Studies in Mediterranean Archaeology, 123/1. Jonsered: Paul Åströms Förlag.

Frankel, D., \& Webb, J. (2006). Marki Alonia: an Early and Middle Bronze Age town in Cyprus: Excavations 1995-2000. Studies in Mediterranean Archaeology, 123/2. Jonsered: Paul Åströms Förlag. 
Frankel, D., Webb, J., \& Pike-Tay, A. (2013). Seasonality and site function in Chalcolithic Cyprus. European Journal of Archaeology, 16(1), 94-115

Fuller, D. Q. (2007). Contrasting patterns in crop domestication and domestication rates: Recent archaeobotanical insights from the Old World. Annals of Botany, 100(5), 903924.

Fuller, D. Q. (2018). Long and attenuated: Comparative trends in the domestication of tree fruits. Vegetation History and Archaeobotany, 27(1), 165-176.

Fuller D. Q, \& Lucas, L. (2017) Adapting crops, landscapes, and food choices: Patterns in the dispersal of domesticated plants across Eurasia. In Boivin N., Petraglia M., \& Crassard, R. (Eds.), Human dispersal and species movement: From prehistory to the present (pp. 304-331). Cambridge: Cambridge University Press.

Fuller, D. Q., \& Stevens, C. J. (2019). Between domestication and civilization: The role of agriculture and arboriculture in the emergence of the first urban societies. Vegetation History and Archaeobotany, 28(3), 263-282.

Fuller, D. Q., Willcox, G., \& Allaby, R. G. (2011). Cultivation and domestication had multiple origins: Arguments against the core area hypothesis for the origins of agriculture in the Near East. World Archaeology, 43(4), 628-652.

Fuller D. Q, Denham, T., Arroyo-Kalin, M., Lucas, L., Stevens, C. J. \& Qin, L. (2014). Convergent evolution and parallelism in plant domestication revealed by an expanding archaeological record. Proceedings of the National Academy of Sciences, 111(17), 61476152.

Fuller, D. Q., Lucas, L., Gonzalez Carretero, L., \& Stevens, C. J. (2018). From intermediate economies to agriculture: Trends in wild food use, domestication and cultivation among early villages in southwest Asia. Paléorient, 44, 61-76. 
Goude, G., Clarke, J., Webb, J. M., Frankel, D., Georgiou, G., Herrscher, E., \& Lorentz, K. O. (2018). Exploring the potential of human bone and teeth collagen from prehistoric Cyprus for isotopic analysis. Journal of Archaeological Science: Reports, 22, 115-122.

Grant, P. R. (1981). Speciation and the adaptive radiation of Darwin's finches. American Scientist, 69, 653-666.

Guilaine, J., \& Briois, F. (2001). Parekklisha Shillourokambos: An Early Neolithic site in Cyprus. In Swiny, S. (Ed.), The earliest prehistory of Cyprus (pp. 37-54). Boston: American Schools of Oriental Research.

Hadjikoumis, A. (2018). Ethnoarchaeology as a means of improving integration: An ethnozooarchaeological study from Cyprus and its contribution to the integration of zooarchaeology with archaeobotany and other lines of archaeological evidence. Environmental Archaeology, 181-198.

Hadjisavvas, S. (2010). Cyprus: Crossroads of civilizations. Nicosia: The Government of the Republic of Cyprus.

Halstead, P. (1987). Traditional and ancient rural economy in Mediterranean Europe: Plus ça change? The Journal of Hellenic Studies, 107, 77-87.

Halstead, P. (2014). Two oxen ahead: Pre-mechanized farming in the Mediterranean. Oxford: Wiley-Blackwell.

Hansen, J. (1991). Palaeoethnobotany in Cyprus: Recent research. In Renfrew, J. M. (Ed.), New light on early farming (pp. 225-236). Edinburgh: Edinburgh University Press. 
Hansen, J. (1994). Khirokitia plant remains: Preliminary report (1986, 1988-1990). In le Brun, A. (Ed.), Fouilles récentes à Khirokitia (Chypre), 1988-1991 (pp. 393-409). Paris: Editions Recherche sur les Civilisations.

Hansen, J. (2001). Aceramic Neolithic plant remains in Cyprus: Clues to their origins? In Swiny, S. (Ed.), The earliest prehistory of Cyprus: From colonization to exploitation (pp. 119-126). Boston: American Schools of Oriental Research.

Harris, D. R. (1989). An evolutionary continuum of people-plant interaction. In D. R. Harris \& G. C. Hillman (Eds.), Foraging and farming: The evolution of plant exploitation (pp. 11-26). London: Routledge,

Harris, D. R. (1996). Introduction: Themes and concepts in the study of early agriculture. In D. R.Harris (Ed.), The origins and spread of agriculture and pastoralism in Eurasia (pp. 1-9). London: UCL Press.

Harris, D. R. (2012). Evolution of agroecosystems: Biodiversity, origins, and differential development. In J. R. Harlan, P. Gepts, T. R. Famula, \& R. L. Bettinger (Eds.), Biodiversity in agriculture: Domestication, evolution, and sustainability. Cambridge University Press (pp. 21-56).

Harris, D. R., \& Fuller, D. Q (2014). Agriculture: Definition and overview. In C. Smith (Ed.), Encyclopedia of global archaeology (pp. 104-113). New York: Springer.

Helbaek, H. (1969). Plant collecting, dry-farming and irrigation agriculture in prehistoric Deh Luran. In F. Hole, K. Flannery \& J. Neely (Eds.), Early prehistory and human ecology of the Deh Luran plain (pp. 383-426). Ann Arbor: University of Michigan. 
Held, S. O. (1989). Colonization cycles on Cyprus. 1: The biogeographic and palaeontological foundation of early prehistoric settlement. Report of the Department of Antiquities, Cyprus 1989, 1-28.

Helmer D., Gourichon L., \& Vila E. (2007). The development of the exploitation of products from Capra and Ovis (meat, milk and fleece) from the PPNB to the Early Bronze in the northern Near East (8700 to 2000 BC cal.). Anthropozoologica, 42(2), 41-69.

Hillman, G., \& Davies, S. (1990). Measured domestication rates in wild wheats and barley under primitive cultivation, and their archaeological implications. Journal of World Prehistory, 42, 157-222.

Hillman, G., Hedges, R., Moore, A., Colledge, S., \& Pettitt, P. (2001). New evidence of Lateglacial cereal cultivation at Abu Hureyra on the Euphrates. Holocene, 11(4), 383393.

Hole, F., Flannery, K., \& Neely, J. (1969). Prehistory and human ecology of the Deh Luran Plain. Memoirs of the Museum of Anthropology, University of Michigan, 1, 383-426.

Holmboe, J. (1914). Studies on the vegetation of Cyprus. Bergen: John Griegs Boktrykkeri.

Horwitz, L., Tchernov, E., \& Hongo, H. (2004). The domestic status of the early Neolithic fauna of Cyprus: A view from the mainland. In Peltenburg, E. J., \& Wasse, A. (Eds.), Neolithic revolution: New perspectives on Southwest Asia in light of recent discoveries on Cyprus (pp. 35-48). Oxford: Oxbow.

Jarman, H., Legge, A., \& Charles, J. (1972). Retrieval of plant remains from archaeological sites by froth flotation. In E. Higgs (Ed.), Problems in economic prehistory (pp. 39-48). Cambridge: Cambridge University Press. 
Kling, B., Muhly, J. D., \& Kassianidou, V. (2007). Joan du Plat Taylor's excavations at the Late Bronze Age mining settlement at Apliki Karamallos, Cyprus. Studies in Mediterranean Archaeology. Göteborg: Paul Åströms Förlag.

Klinge, J., \& Fall, P. (2010). Archaeobotanical inference of Bronze Age land use and land cover in the eastern Mediterranean. Journal of Archaeological Science, 37(10), 26222629 .

Knapp, A. (1990). Production, location and integration in Bronze Age Cyprus. Current Anthropology, 31, 147-176.

Knapp, A. (1993). Social complexity: Incipience, emergence, and development on prehistoric Cyprus. Bulletin of the American Schools of Oriental Research 292, 5-106.

Knapp, A. (2008). Prehistoric and protohistoric Cyprus: Identity, insularity and connectivity. Oxford: Oxford University Press.

Lambeck K., \& Purcell A. (2005). Sea-level change in the Mediterranean Sea since the LGM: Model predictions for tectonically stable areas. Quaternary Science Review 24, 18 19.

Lange-Badré, B., \& Le Mort, F. (1998). Isotopes stables du carbone et de l'azote et éléments traces indicateurs du régime alimentaire de la population néolithique de Khirokitia (Chypre). In L'homme préhistorique et la mer: Actes du $120^{\circ}$ Congrès national des sociétés historiques et scientifiques, section de Pré-et Protohistoire, Aix-en Provence (23-26 Octobre 1995). Paris: CTHS, 415-426.

Larson, G., \& Fuller, D. Q (2014). The evolution of animal domestication. Annual Review of Ecology Evolution and Systematics, 66, 115-136. 
Larson, G., Piperno, D. R., Allaby, R. G., Purugganan, M. D., Andersson, L., Arroyo-Kalin, M., et al. (2014) Current perspectives and the future of domestication studies. Proceedings of the National Academy of Sciences, 111(17): 6139-6146.

Legge, A. J. (1982). The vertebrate fauna. In Peltenburg, E. J. (Ed), Vrysi: A subterranean settlement in Cyprus. Excavations at prehistoric Ayios Epiktitos-Vrysi 1969-73 (pp. 7687, 401-414). Warminster: Aris \& Phillips.

Lentini, A. (2009). Indagini archeobotaniche e fisico chimiche. In M. R. Belgiorno (Ed.), Cipro all'inizio dell'Età del Bronzo, Realtà Sconosciute della Comunità Industriale di Pyrgos-Mavrorachi (pp. 129-187). Rome: Gangemi Editore.

Losos, J. B., \& Ricklefs, R. E. (2009). Adaptation and diversification on islands. Nature, $457,830-836$.

Lucas, L. (2014). Crops, culture, and contact in prehistoric Cyprus. BAR International Series 2639. Oxford: Archaeopress.

Lucas, L., Colledge, S., Simmons, A., \& Fuller, D. Q, (2012). Crop introduction and accelerated island evolution: Archaeobotanical evidence from 'Ais Yiorkis and PrePottery Neolithic Cyprus. Vegetation History and Archaeobotany, 21(2), 117-129.

Lucas, L., \& Fuller, D.Q. (2018). From intermediate economies to agriculture: Trends in wild food use, domestication and cultivation among early villages in southwest Asia. Dataset. UCL Institute of Archaeology: London, UK. [Dataset]http://discovery.ucl.ac.uk/id/eprint/10052960

MacArthur, R. H., \& Wilson, E. O. (1967). The theory of island biogeography. Princeton, NJ: Princeton University Press. 
Maeda, O., Lucas, L., Silva, F., Tanno, K-I., \& Fuller, D. Q (2016). Narrowing the harvest: Increasing sickle investment and the rise of domesticated cereal agriculture in the Fertile Crescent. Quaternary Science Reviews, 145, 226-237.

Manning, S. W., McCartney, C., Kromer, B., \& Stewart, S. T. (2010). The earlier Neolithic in Cyprus: Recognition and dating of a Pre-Pottery Neolithic A occupation. Antiquity 84, 693-706.

Manning, S. (1993). Prestige, distinction and competition: The anatomy of socioeconomic complexity in 4th-2nd millennium BCE Cyprus. Bulletin of the American Schools of Oriental Research, 292, 35-58.

McCartney, C. (2005). Preliminary report on the resurvey of three Early Neolithic sites in Cyprus. Report of the Department of Antiquities, Cyprus, 1-22.

McCartney, C., \& Gratuze, B. (2003). The Chipped Stone. In Peltenburg, E. J. (Ed.), The colonisation and settlement of Cyprus: Investigations at Kissonerga-Mylouthkia 19761996 (pp. 11-34). Sävedalen: Paul Åströms Förlag.

McCartney, C., Manning, S., Sewell, D., \& Stewart, S. (2006). Elaborating Early Neolithic Cyprus (EENC). Report of the Department of Antiquities, Cyprus, 39-62.

McCartney, C., Manning, S., Sewell, D., \& Stewart, S. (2007). The EENC 2006 field season: Excavations at Agia Varvara-Asprokremmos and survey of the local early Holocene landscape. Report of the Department of Antiquities, Cyprus, 27-44.

McClatchie, M., Bogaard, A., Colledge, S., Whitehouse, N. J., Schulting, R. J., Barratt, P., \& McLaughlin, R. T. (2014) Neolithic farming in northwestern Europe: Archaeobotanical evidence from Ireland. Journal of Archaeological Science, 51, 206-215. 
Meadow, R. H. (1989). Osteological evidence for the process of animal domestication. In Clutton-Brock, J. (Ed.), The walking larder: Patterns of domestication, pastoralism, and predation (pp. 80-90). London: Unwin Hyman.

Meikle, R. D. (1977). Flora of Cyprus. London: Kew.

Meikle, R. D. (1985). Flora of Cyprus. London: Kew.

Michaelides, S. C., Tymvios, F. S., \& Michaelidou, T. (2009). Spatial and temporal characteristics of the annual rainfall frequency distribution in Cyprus. Atmospheric Research, 944, 606-615.

Miller N.F. (2011) Reconciling nature and culture after 'Naissance des divinités, Naissance de L'agriculture'. Paléorient, 37(1), 61-74

Morrison, K. D. (1994). The intensification of production: Archaeological approaches. Journal of Archaeological Method and Theory, 1(2), 111-59.

Murray, M. A. (1998). Archaeobotanical report. In Peltenburg, E. J. (Ed.), Lemba Archaeological Project. Volume II. 1A: Excavations at Kissonerga-Mosphilia, 1979-1999 (pp. 215-223). Sävedalen: Paul Åströms Förlag.

Murray, M. A. (2003). The plant remains. In E. J. Peltenburg (Ed.), The colonisation and settlement of Cyprus: Investigations at Kissonerga-Mylouthkia 1976-1996 (pp. 59-71). Sävedalen: Paul Åströms Förlag.

O'Connell, J. F., Allen, J. \& Hawkes, K. (2010). Pleistocene Sahul and the origins of seafaring. In A. Anderson, J. H. Barrett, \& K. V. Boyle (Eds.), The global origins and development of seafaring (pp. 57-68). Cambridge: McDonald Institute for Archaeological Research. 
Peltenburg, E. (1982). Recent developments in the later prehistory of Cyprus. Studies in Mediterranean Archaeology, Pocketbook 16. Göteborg: Paul Åströms Forlag.

Peltenburg, E. (1996). From isolation to state formation in Cyprus, c. $3500-1500$ BC. In V. Karageorghis \& D. Michalides (Eds.), The development of the Cypriot economy from the prehistoric period to the present day (pp. 17-43). Nicosia: University of Cyprus and the Bank of Cyprus.

Peltenburg, E. (2003). Conclusions: Mylouthkia 1 and the early colonists of Cyprus. In Peltenburg, E. J. (Ed.), The colonisation and settlement of Cyprus: Investigations at Kissonerga-Mylouthkia 1976-1996 (pp. 83-106). Sävedalen: Paul Åströms Förlag.

Peltenburg, E., Bolger, D., Croft, P., Goring, E., Irving, B., Lunt, D., et al. (Eds.) (1998). Lemba Archaeological Project Volume II.1 A: Excavations at Kissonerga-Mosphilia, 1979-1992. Sävedalen: Paul Åströms Förlag.

Peltenburg, E. (2004a). Introduction. In E. Peltenburg \& A. Wasse (Eds.), Neolithic Revolution: New perspectives on Southwest Asia in light of recent discoveries on Cyprus (pp. xi-xix). Oxford: Oxbow.

Peltenburg, E. (2004b). Social space in early sedentary communities of Southwest Asia and Cyprus. In E. Peltenburg \& A. Wasse (Eds.), Neolithic Revolution: New perspectives on Southwest Asia in light of recent discoveries on Cyprus (pp. 71-89). Oxford: Oxbow.

Peltenburg, E., Baird, D., Betts, A., Colledge, S., Croft, P., Elliot, C., et al. (1985). Lemba Archaeological Project I: Excavations at Lemba Lakkous, 1976-1983. Studies in Mediterranean Archaeology, Göteborg: Paul Åströms Förlag. 
Peltenburg, E., Bolger, D., Colledge, S., Croft, P., Fox, S., Goring, E., et al. (2003). The colonisation and settlement of Cyprus: Investigations at Kissonerga Mylouthkia, 19761996. Sävedalen: Paul Åströms Förlag.

Peltenburg, E. Colledge, S., Croft, P., Jackson, A., McCartney C., \& Murray, M. A. (2000). Agro-pastoralist colonization of Cyprus in the 10th millennium BP: Initial assessments. Antiquity, 74, 844-853.

Peltenburg, E., Colledge, S., Croft, P., Jackson, A., McCartney, C., \& Murray, M. A. (2001). Neolithic dispersals from the Levantine corridor: A Mediterranean perspective. Levant, 33, 35-64.

Price, D. T. \& Bar-Yosef, O. (2011). The origins of agriculture: New data, new ideas. Current Anthropology: An introduction to Supplement 4, S163-S174.

Reimer, P. J., Baillie, M. G. L., Bard, E., Bayliss, A., Beck, J. W., Bertrand, C. J. H., et al. (2004). IntCal04 terrestrial radiocarbon age calibration, 0- 26 cal kyr BP. Radiocarbon, 46(3), 1029-58.

Riehl, S., \& Kümmel, C. (2005). Archaeobotanical database of eastern Mediterranean and Near Eastern sites. http://www.cuminum.de/archaeobotany.

Rollefson, G. O. (2003). The Neolithic period. In Richard, S. (Ed.), Near Eastern archaeology: A reader (pp. 244-253). Winona Lake, IN: Eisenbrauns.

Şevketoğlu, M. (2000). Archaeological field survey of the Neolithic and Chalcolithic settlement sites in Kyrenia District, North Cyprus. BAR international Series 834. Oxford: J. \& E. Hedges. 
Sciré Calabrisotto, C. S. (2017). Paleodiet reconstruction. In Bombardieri, L. (Ed.), Erimi Laonin tou Porakou: A Middle Bronze Age community in Cyprus. Excavations 2008-2014 (p. 145). Uppsala: Paul Åströms Forlag.

Shennan, S., Downey, S. S., Timpson, A., Edinborough, K., Colledge, S., Kerig, T., Manning, K. \& Thomas, M. G., (2013). Regional population collapse followed initial agriculture booms in mid-Holocene Europe. Nature Communications, 4, 2486.

Sherratt, A. (1980). Water, soil and seasonality in early cereal cultivation. World Archaeology, 113, 313-330.

Sherratt, A. (1981) Plough and pastoralism: Aspects of the secondary products revolution. In I. Hodder, G. Isaac \& N. Hammond (Eds.), Pattern of the past. Cambridge: Cambridge University Press.

Simmons, A. H. (1998). Test excavations at two Aceramic Neolithic sites in the uplands of Western Cyprus. Report of the Department of Antiquities, Cyprus, 1-16.

Simmons, A. H. (1999). Faunal extinction in an island society: Pygmy hippopotamus hunters of Cyprus. New York: Kluwer Acad., Plenum Publ.

Simmons, A. H. (2004). Bitter hippos on Cyprus: The island's first occupants and last endemic animals - setting the stage for colonization. In E. Peltenburg \& A. Wasse (Eds.), Neolithic revolution: New perspectives on Southwest Asia in light of recent discoveries on Cyprus (pp. 1-14). Oxford: Oxbow.

Smith, B. D. (2001). Low-level food production. Journal of Archaeological Research, 9(1), $1-43$.

Spigelman, M. (2006). Investigating the faunal record from Bronze Age Cyprus: Diversification and intensification. In A. P McCarthy (Ed.), Island dialogues: Cyprus in the 
Mediterranean network (pp. 119-129). University of Edinburgh Archaeology, Occasional Paper.

Steel, L. (2004). Cyprus before history: From the earliest settlers to the end of the Bronze Age. London: Duckworth/Cambridge University Press.

Stevens, C. J. \& Fuller, D. Q., (2015). Alternative strategies to agriculture: The evidence for climatic shocks and cereal declines during the British Neolithic and Bronze Age (a reply to Bishop). World Archaeology, 47(5), 856-875.

Stewart, R. (1974). Paleobotanic investigation: 1972 Season. In Stager, L., Walker, A., Wright, E. (Eds.), American expedition to Idalion, Cyprus, first preliminary report: Seasons of 1971 and 1972 (pp. 123-129). Cambridge, MA: The American Schools of Oriental Research.

Struever, S. (1968). Flotation techniques for the recovery of small-scale archaeological remains. American Antiquity, 33(3), 353-362.

Styring, A. K., Charles, M., Fantone, F., Hald, M. M., McMahon, A., Meadow, R. H., et al. (2017). Isotope evidence for agricultural extensification reveals how the world's first cities were fed. Nature Plants, 3(6), nplants201776.

Thoma, G. (2014). Agriculture at Bronze Age Kissonerga-Skalia, Cyprus: An archaeobotanical case study. Unpublished MSc Dissertation. University College London.

Trigger, B. (2003). Understanding early civilizations. Cambridge: Cambridge University Press.

Tsintides, T. C., (1998). The endemic plants of Cyprus. Nicosia: Bank of Cyprus Group: Cyprus Association of Professional Foresters. 
Valamoti, S. M. (2004). Plants and people in Late Neolithic and Early Bronze Age Northern Greece: An archaeobotanical investigation. British Archaeolological Report S1258.Oxford: Archaeopress.

Valamoti, S. M. \& Charles, M., (2005). Distinguishing food from fodder through the study of charred plant remains: An experimental approach to dung-derived chaff. Vegetation History and Archaeobotany, 14(4), 528-533.

van Zeist, W. (1970). The Oriental Institute excavations at Mureybiț, Syria: Preliminary report on the 1965 Campaign. Part III: The paleobotany. Journal of Near Eastern Studies 29(3), 167-176.

van Zeist, W. (1981). Plant remains from Cape Andreas-Kastros (Cyprus). In le Brun, A. (Ed.), Un site néolithique précéramique en Chypre: Cap Andreas-Kastros (pp. 95-99). Paris: Recherche sur les grandes civilisations.

Vigne, J-D. (2011). The origins of animal domestication and husbandry: A major change in the history of humanity and the biosphere. Comptes Rendus Biologies, 334(3), 171181.

Vigne J.-D. (2015) Early domestication and farming: What should we know or do for a better understanding? Anthropozoologica 50(2), 123-150.

Vigne J-D., \& Buitenhuis, H. (1999) Les premiers pas de la domestication animale à l'Ouest de l'Euphrate : Chypre et l'Anatolie centrale. Paléorient, 25, 49-62.

Vigne J-D., \& Helmer D. (2007). Was milk a 'secondary product' in the Old World Neolithisation process? Its role in the domestication of cattle, sheep and goats. Anthropozoologica, 42 (2), 9-40. 
Vigne, J-D., Carrère, I., \& Saliège, J. F., (2000). Predomestic cattle, sheep, goat and pig during the late 9th and the 8th millennium cal. BC on Cyprus: Preliminary results of Shillourokambos (Parekklisha, Limassol). In F. Mashkour, A. M. Choyke, \& H. P. F. Buitenhuis (Eds.) Archaeozoology of the Near East Iva. Publicaties 32 (pp. 83-106). Groningen, The Netherlands: Archaeological Research and Consultancy.

Vigne, J.-D., Carrère, I., \& Guilaine, J. (2003). Unstable status of early domestic ungulates in the Near East: The example of Shillourokambos (Cyprus, IXth-VIIIth millennia cal. BC). Bulletin de Correspondence Hellénique-Supplement, 43, 239-252.

Vigne, J.-D., Guilaine, J., Debue, K., Haye, L., Gérard, P. (2004). Early taming of the cat in Cyprus. Science, 304, 259.

Vigne, J-D., Zazza, A., Saliage, J-F., Poplin, F., Guilaine, J, \& Simmons, A. (2009). PreNeolithic wild boar management and introduction to Cyprus more than 11,400 years ago. Proceedings of the National Academy of Sciences, 106(38), 16135-16138.

Vigne, J-D., Carrère, I., Briois, F., Guilaine, J., (2011). The early process of mammal domestication in the Near East: New Cypriot Pre-Neolithic and Pre-Pottery Neolithic Evidence. Current Anthropology, 52 (Supplement 4), 255-271.

Vigne, J-D., Briois, F., Zazzo, A., Willcox, G., Cucchi, T., Thiébault, S., et al. (2012). First wave of cultivars spread to Cyprus at least $10,600 \mathrm{y}$ ago. Proceedings of the National Academy of Sciences of the United States of America, 109(22), 8445-8449.

Vigne, J-D., Zazzo, A., Cucchi, T., Carrère, I., Briois, F., \& Guilaine, J., (2014). The transportation of mammals to Cyprus sheds light on early voyaging and boats in the Mediterranean Sea. Eurasian Prehistory, 10(1-2), 157-176. 
Vigne, J-D., Daujat, J., \& Monchot, H. (2015). First Introduction and early exploitation of the Persian fallow deer on Cyprus (8000-6000 cal. BC). International Journal of Osteoarchaeology, 26(5), 853-866.

Vigne, J-D., Briois, F., Cucchi, T., Franel, Y., Mylona, P., Tengberg, M., Touquet, R., Wattez, J., Willcox, G., Zazzo, A., \& Guilaine, J. (2017). Klimonas, a late PPNA huntercultivator village in Cyprus: new results. In J-D. Vigne, F. Briois \& M. Tengberg (Eds.), Nouvelles données sur les débuts du Néolithique à Chypre / New data on the beginning of the Neolithic in Cyprus, Séances en ligne 9 pp. 21-46.

Waines, J., \& Price, N. S. (1977). Plant remains from Khirokitia in Cyprus. Paléorient, 5, 281-284.

Wallace, M., Jones, G., Charles, M., Forster, E., Stillman, E., Bonhomme, V., Livarda, A., Osborne, C. P., Rees, M., Frenck, G., \& Preece, C. (2019) Re-analysis of archaeobotanical remains from pre- and early agricultural sites provides no evidence for a narrowing of the wild plant food spectrum during the origins of agriculture in southwest Asia. Vegetation History and Archaeobotany, 28(4), 449-463.

Wasse, A. (2007). Climate, economy, and change: Cyprus and the Levant during the late Pleistocene-mid-Holocene. In J. Clarke, C. McCartney \& A. Wasse (Eds.), On the margins of Southwest Asia: Cyprus during the 6th and 4th millennia BC (pp. 43-63). Oxford: Oxbow.

Weiss, E. (2015). 'Beginnings of fruit growing in the Old World' - two generations later. Israel Journal of Plant Sciences, 62(1-2), 75-85.

Webb, J. M., Frankel, D., Croft, P., \& McCartney, C. (2009). Excavations at Politiko Kokkinorotsos. A Chalcolithic hunting station in Cyprus. Proceedings of the Prehistoric Society, 75, 189-237. 
White, C. E., \& Makarewicz, C. (2011). Harvesting practices and early Neolithic barley cultivation at el-Hemmeh, Jordan. Vegetation History and Archaeobotany, 21(2), 85-94.

Whitehouse, N. J., Schulting, R. J., McClatchie, M., Barratt, P., McLaughlin, T. R., Bogaard, A., Colledge, S., Marchant, R., Gaffrey, J., \& Bunting, M. J. (2014). Neolithic agriculture on the European western frontier: The boom and bust of early farming in Ireland. Journal of Archaeological Science 51, 181-205.

Wilkinson, K. N., \& Stevens, C. J. (2008). Environmental archaeology: Approaches, techniques and applications. Revised edition. Stroud:Tempus.

Willcox, G. (2003a). The origins of Cypriot farming. In J. Guilaine \& le A. Brun (Eds.), Le Néolithique de Chypre (pp. 231-238). Nicosia: Actes du Colloque International.

Willcox, G. (2003b). Chalcolithic carbonised cereals from Ubaid burnt storage structures at Kosak Shamali. In Y. Nishiaki \& T. Matsutani (Eds), Tell Kosak Shamali. Vol. II (pp. 267-270). Tokyo: University Museum.

Willcox, G. (2012). Searching for the origins of arable weeds in the Near East. Vegetation history and archaeobotany, 21(2), 163-167.

Zeder, M. A. (2006). Central questions in the domestication of plants and animals. Evolutionary Anthropology: Issues, News, and Reviews, 15(3), 105-117.

Zeder, M. A. (2008). Domestication and early agriculture in the Mediterranean Basin: Origins, diffusion, and impact. Proceedings of the National Academy of Sciences of the United States of America, 105(33), 11597-11604.

Zohary, D., 1973. Geobotanical foundations of the Middle East. Stuttgart: Fischer. 
Zohary, D., \& Hopf, M. (2000). Domestication of plants in the Old World: The origin and spread of cultivated plants in West Asia, Europe and the Nile Valley. Oxford: Oxford University Press. 


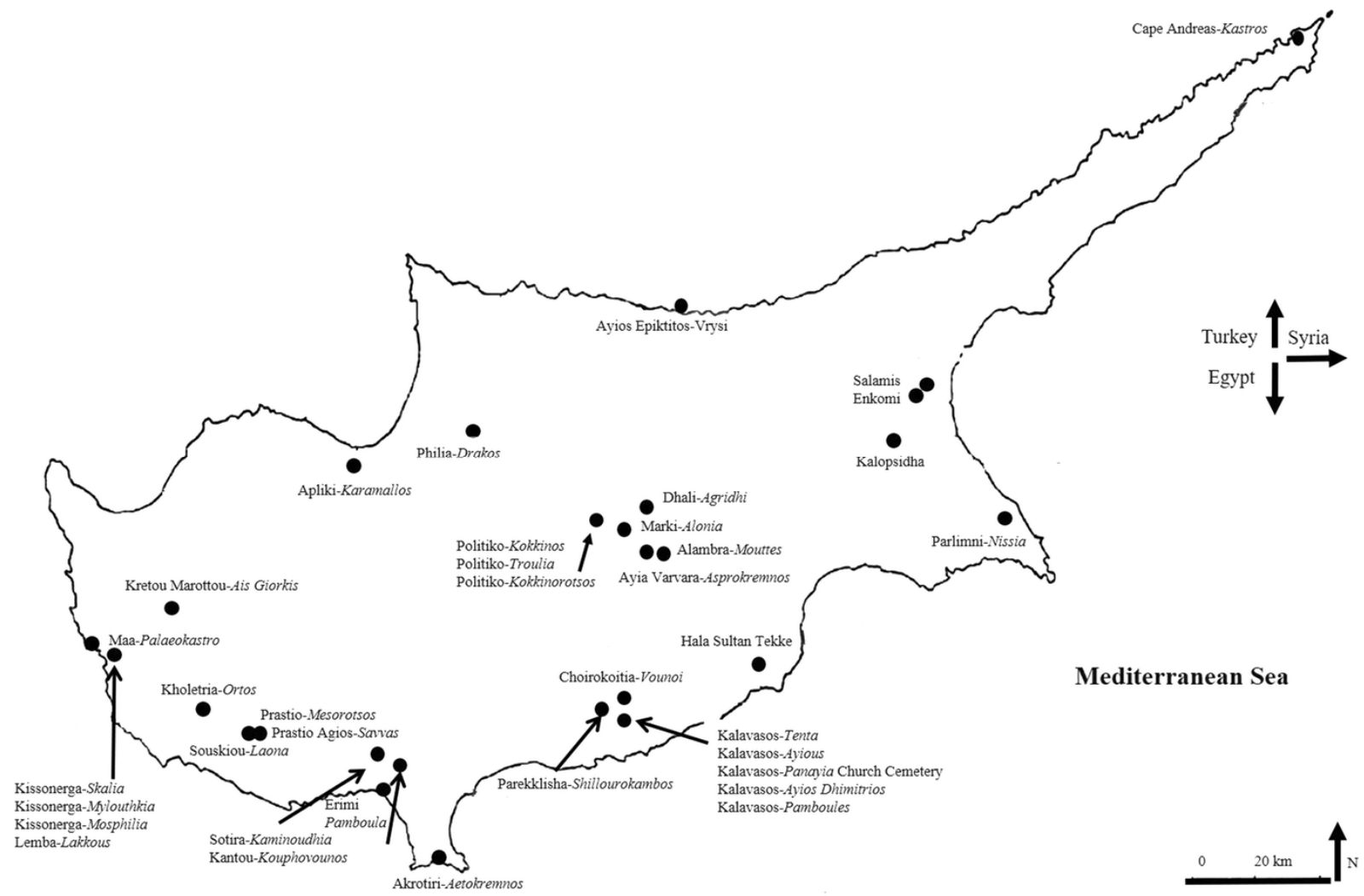

Figure 1. Map of Cyprus showing the location of sites with archaeobotanical and zooarchaeological data 


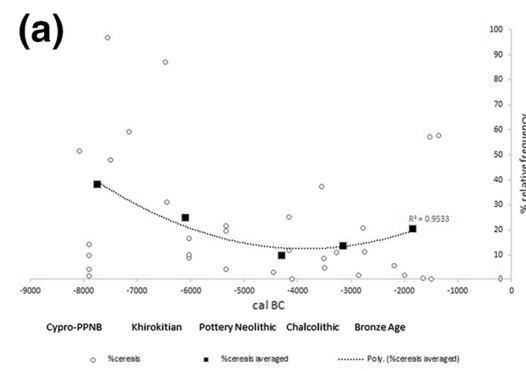

(d)

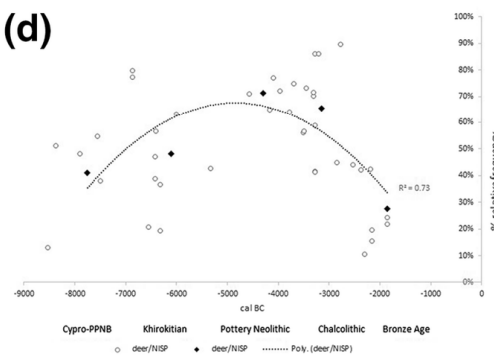

(b)

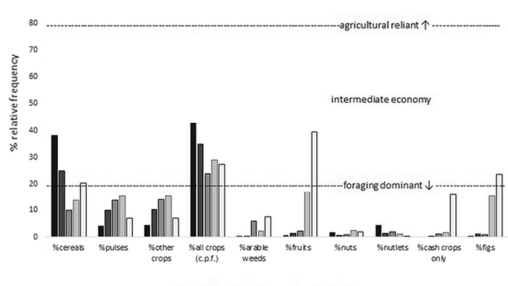

(c)

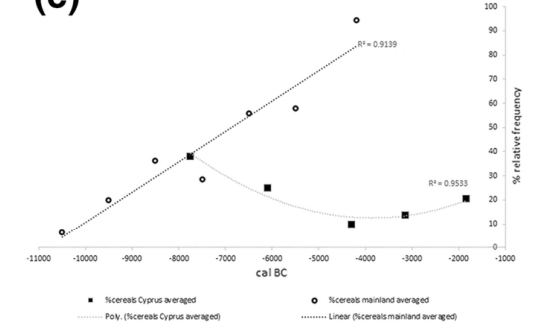

(e)

$\infty$

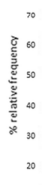

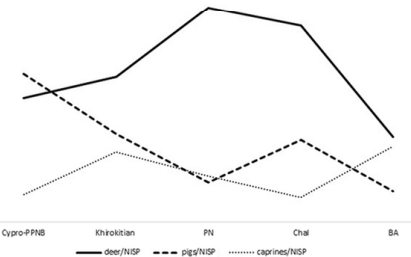

Figure 2. a Cereal frequency at individual sites in Cyprus. Each dot represents an individual site for which data for \% cereal is available. Each filled square represents the 'binned' data for each broad cultural phase based on the median calibrated date ranges. b Frequencies of crops, fruits, nuts, nutlets, figs, and cash crops from sites dated from the Neolithic to Bronze Age in Cyprus. The data are 'binned' according to each broad cultural phase, based on the median calibrated date ranges. c Cereal frequencies in Cyprus and the mainland Levant. Each dot represents the 'binned' data from each broad cultural phase for mainland Levantine sites based on the median calibrated date ranges. Each filled square represents the 'binned' data from each broad cultural phase for Cypriot sites, based on the median calibrated date ranges. d Relative contribution to the meat supply for faunal taxa at individual sites in Cyprus. Each dot represents an individual site for which data for \% fauna is available. Each filled diamond represents the 'binned' data for each broad cultural phase, based on the median calibrated date ranges. e Relative contribution to the meat supply for deer, pig and caprine in Cyprus. The data are 'binned' according to each broad cultural phase, based on the median calibrated date ranges 


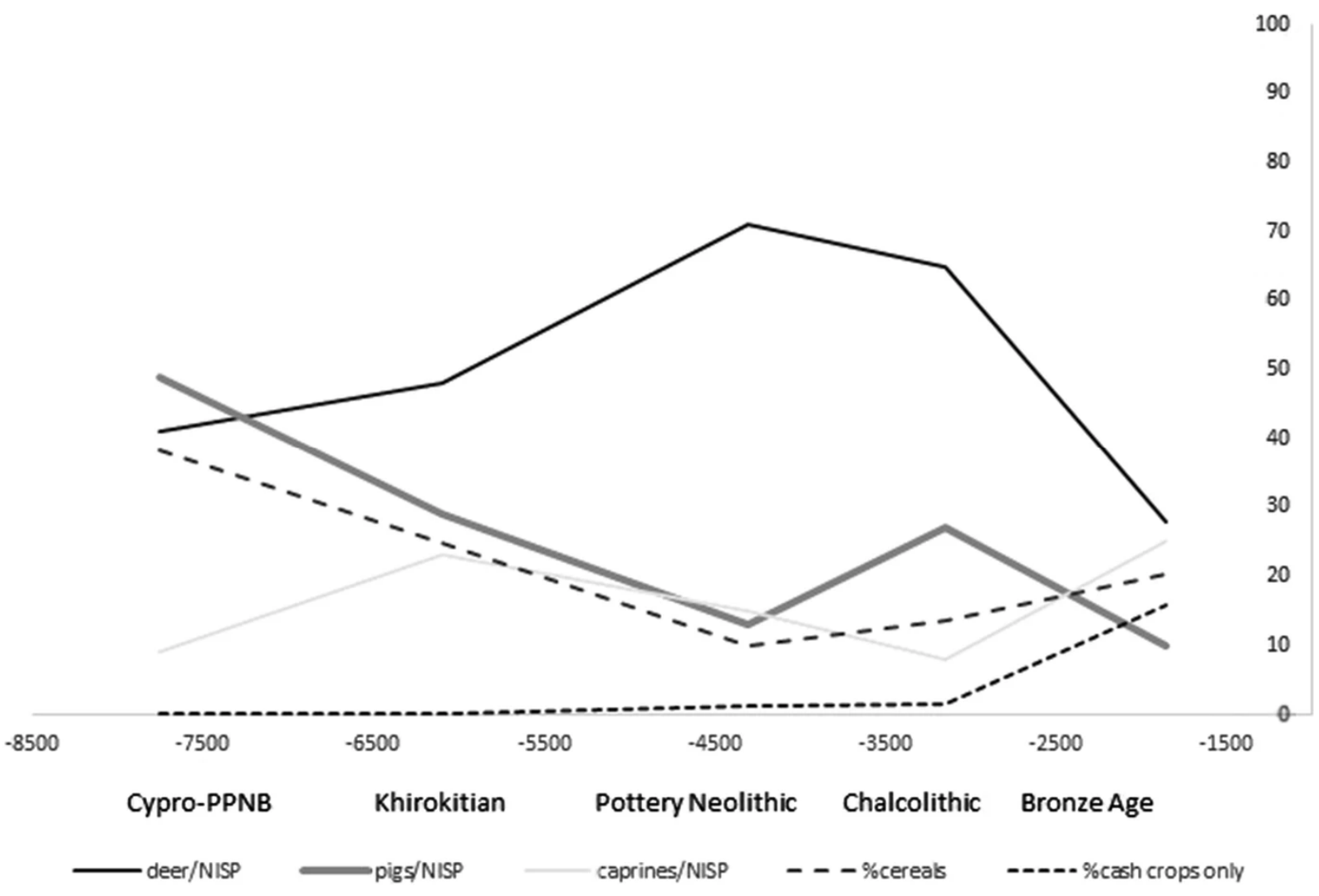

Figure 3. Relative contribution to the meat supply for deer, pig, and caprine and the frequencies of cereals and cash crops in Cyprus. The data are 'binned' according to each broad cultural phase, based on the median calibrated date 